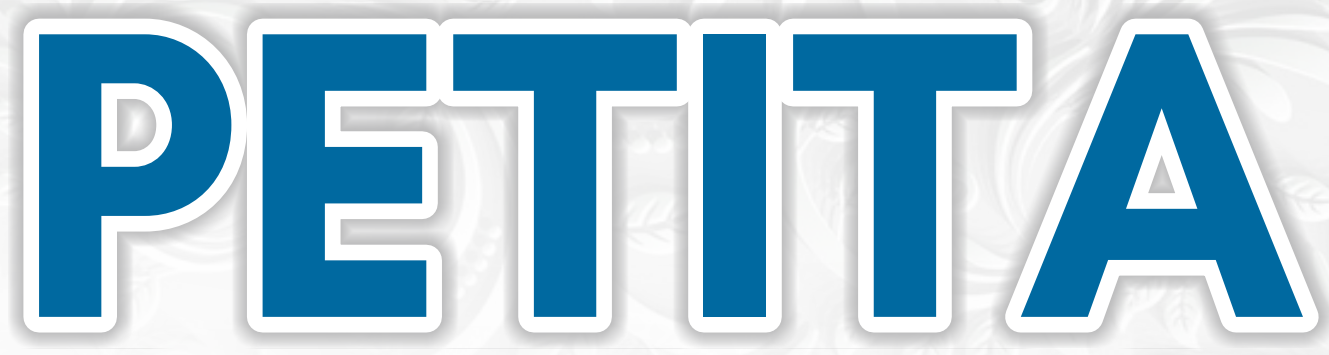

Jurnal Kajian Ilmu Hukum dan Syariah

Published By:

Lembaga Kajian Konstitusi Indonesia (LKKI)

Fakultas Syariah dan Hukum Universitas Islam Negeri (UIN) Ar-Raniry Banda Aceh Jl. Syeikh Abdul Rauf, Kopelma Darussalam Banda Aceh, Telp: 0651-7557442 Website: http://petita.ar-raniry.ac.id 


\section{Contents}

TES DNA SEBAGAI ALAT BUKTI PENGGANTI EMPAT ORANG SAKSI (ANALISIS QANUN ACEH NOMOR 6 TAHUN 2014 TENTANG HUKUM JINAYAH)

(Era Fadli, Mursyid Djawas \& Syarifah Rahmatillah / 1-9)

SISTEM JAMINAN KESELAMATAN KERJA KARYAWAN BENGKEL LAS MENURUT PERSPEKTIF HUKUM ISLAM DAN UNDANG-UNDANG NO.13 TAHUN 2003 TENTANG KETENAGAKERJAAN (Studi Kasus Kecamatan Tanah Jambo Aye)

(Lilis Diatana, Edi Darmawijaya \& Faisal Fauzan / 10-23)

PERTANGGUNGAN RISIKO TERHADAP SEJUMLAH MINYAK YANG SUSUT DALAM MASA PENGANGKUTAN (Studi Kasus pada PT.Citra Bintang Familindo)

(Mayliza / 24-35)

KEDUDUKAN MEMORANDUMOF UNDERSTANDING (MOU) HELSINKI DALAM PEMBENTUKAN UNDANG- UNDANG NOMOR 11 TAHUN 2006 TENTANG PEMERINTAHAN ACEH

(Qonita Royani Salpina, Rusjdi Ali Muhammad \& Yenny Sriwahyuni / 36-46)

PELELANGAN OBJEK JAMINAN MURABAHAH PADA BANK SYARIAH MANDIRI CABANG BANDA ACEH MELALUI KANTOR PELELANGAN KEKAYAAN NEGARA DAN LELANG DALAM PERSPEKTIF BAI' AL-MUZAYYADAH

(Reza Fahmi / 47-63)

PENERAPAN SANKSI TINDAK PIDANA ILLEGAL LOGGING DI KAWASAN HUTAN LINDUNG DITINJAU DARI DARI UU NO. 18 TAHUN 2013 TENTANG PENCEGAHAN DAN PEMBERANTASAN PERUSAKAN HUTAN (Studi Kasus Kecamatan Bener Kelipah Kabupaten Bener Meriah)

(Ali Abu Bakar, Mizaj Iskandar \& Reza Maulana / 64-74)

EFEKTIVITAS PELAKSANAAN SANKSI TALAK DI LUAR MAHKAMAH RENDAH SYARIAH (STUDI KASUS DI MAHKAMAH RENDAH SYARIAH SELANGOR, MALAYSIA)

(Rukiah M. Ali \& Siti Maimunah Binti Mohd Rijal / 75-95)

SISTEM PERLINDUNGAN PEMKAB ACEH BESAR TERHADAP PERTAMBANGAN BATUAN DALAM PERSPEKTIF MILK AL-DAULAH (PENELITIAN PADA TAMBANG BATUAN DI KECAMATAN INDRAPURI)

(Siti Rohaya / 96-103) 


\title{
EFEKTIVITAS PELAKSANAAN SANKSI TALAK DI LUAR MAHKAMAH RENDAH SYARIAH (Studi Kasus Di Mahkamah Rendah Syariah Selangor, Malaysia)
}

\author{
Rukiah M. Ali \\ Siti Maimunah Binti Mohd Rijal \\ Prodi Hukum Keluarga Fakultas Syari'ah dan Hukum \\ UIN Ar-Raniry Banda Aceh \\ Email: rukiah@ar-raniry.ac.id
}

\begin{abstract}
This article examined the problem to reduce divorces outside the court. The Malaysian government has established sanctions for the perpetrators. This research was conducted employing a case study approach with descriptive-analysis method. The results showed that the implementation of divorce sanctions outside the Syariah Subordinate Court of Selangor was less effective in reducing divorces. The high number of divorce cases were found in the country of Selangor, increasing by $71.8 \%$ of cases from 2012 to 2017. However, the cases in the West Gombak Syariah Subordinate Court has decreased slightly between 2015 and 2017, indicated by only a few cases were registered. Two factors influenced the implementation of divorce sanctions outside the Syariah Subordinate Court. First, the Selangor Islamic Family Law has regulated the divorce law outside the court in a detailed and clear. Still, the socialization for the public was lacking, and the society took this rule seriously so that the sanction implementation for divorce cases outside the court became a legal solution. Second, the high number of divorce cases found outside the court required a legal policy to impose a legal sanction on the perpetrators.
\end{abstract}

Keywords: Effectiveness, Sanctions, Divorce, Outside The Court

Abstrak: Artikel berjudul “ Efektivitas Pelaksanaan Sanksi Talak di Luar Mahkamah Rendah Syariah (Studi Kasus Mahkamah Rendah Syariah Selangor, Malaysia ) ini ditulis untuk mengkaji masalah untuk mengurangi talak di luar Mahkamah, pemerintah Malaysia telah menetapkan sanksi bagi pelaku. Jadi, permasalahan penelitian ini adalah: (1) Bagaimana efektivitas pelaksanaan sanksi talak di luar Mahkamah Rendah Syariah Selangor? (2) Faktor-faktor apa yang mempengaruhi pelaksanaan sanksi talak di luar Mahkamah Rendah Syariah Selangor? (3) Bagaimana tinjauan Hukum Islam terhadap pelaksanaan sanksi talak di luar mahkamah? Penelitian ini dilakukan dengan pendekatan studi kasus dengan metode deskriptif-analisis. Hasil penelitian menunjukkan bahwa: Pelaksanaan sanksi talak di luar Mahkamah Rendah Syariah Selangor masih kurang efektif dalam mengurangi perceraian. Kasus perceraian ditemukan cukup banyak di negeri Selangor sebanyak 71.8\% kasus meningkat dari tegang waktu tahun 2012 hingga 2017 namun kisaran kasus di Mahkamah Rendah Syariah Gombak Barat agak sudah sedikit menurun dari tahun 2015 hingga 2017 hanya ditemukan beberapa kasus yang terdaftar. Faktorfaktor yang mempengaruhi pelaksanaan sanksi talak di luar Mahkamah Rendah Syariah Selangor ada dua. Pertama, Enakmen Hukum Keluarga Islam Negeri Selangor telah diatur hukum perceraian di luar mahkamah secara rinci dan jelas, namun masyarakat masih 
kurang sosialisasi dan mengambil berat terhadap aturan ini sehingga penerapan sanksi atas kasus talak di luar mahkamah muncul sebagai solusi hukumnya. Kedua, banyaknya temuan kasus talak di luar mahkamah mengharuskan adanya kebijakan hukum berupa penjatuhan sanksi hukum bagi pelakunya. Pelaksanaan sanksi talak di luar mahkamah tidak menyalahi hukum Islam. pelaksanaan sanksi hukum atas kasus talak di luar mahkamah dilandasai atas kemaslahatan masyarakat, mengatur tertib dan praktis talak secara baik sehingga suami tidak sewenang-wenang menjatuhkan talak.

\section{Kata Kunci: Efektivitas, Sanksi, Talak, Luar Mahkamah}

\section{Pendahuluan}

Artikel ini akan memaparkan tentang penetapan sanksi talak di luar Mahkamah. Sebelum masuk dalam pokok persoalan, penting dikemukakan bahwa perkawinan adalah sunnatullah bagi umat manusia, hal ini ditetapkan Allah untuk menjaga kehormatan umat manusia dan juga untuk membedakan umat manusia dengan makhluk lainnya. Sudah menjadi kodrat segala sesuatu yang ada di dunia ini mempunyai pasangan masing-masing. Dalam al-Qur'an Allah berfirman dalam surat Ar-rum ayat 21:

Dan segala sesuatu Kami ciptakan berpasangan-pasangan kamu mengingat kebesaran Allah. ${ }^{1}$

Akad perkawinan dalam hukum Islam bukanlah perkara perdata semata, melainkan ikatan suci yang terkait dengan keyakinan dan keimanan. Perkawinan harus dipelihara dengan baik sehingga bisa abdi dan yang menjadi tujuan perkawinan dalam Islam yakni terwujudnya keluarga sejahtera (mawaddah wa rahmah) dapat terwujud. ${ }^{2}$ Khoirudin Nasution menyimpul ada lima prinsip perkawinan yakni: (1) prinsip musyawarah dan demokrasi, (2) prinsip menciptakan rasa aman, nyaman, dan tenteram dalam kehidupan keluarga, (3) prinsip menghindari dari kekerasan, (4) prinsip bahwa hubungan suami dan istri adalah patner, dan (5) prinsip keadilan. ${ }^{3}$

Perkawinan adalah ikatan suci antara suami istri namun tidak boleh dipandang mutlak atau tidak boleh dianggap tidak dapat diputuskan. Perkawinan Islam tidak boleh dipandang sebagai sebuah sakramen seperti yang terdapat di dalam agama Hindu dan Kristen, sehingga tidak dapat diputuskan. Ikatan perkawinan harus dipandang sebagai sesuatu yang alamiah, bisa bertahan dengan bahagia sampai ajal menjelang dan bisa juga putus di tengah jalan. ${ }^{4}$ Abu A'la Al-Maududi seperti dikutip oleh Rahmat Hakim dalam bukunya yang berjudul Hukum Perkawinan Islam mengatakan, salah satu prinsip hukum perkawinan Islam adalah bahwa perkawinan itu harus dipertahankan sedapat mungkin agar tidak terjadi perceraian. Oleh karena itu, segala usaha harus dilakukan agar persekutuan tersebut dapat terus berlangsung. Namun, apabila semua harapan dan kasih sayang telah musnah dan perkawinan menjadi suatu yang membahayakan sasaran hukum untuk kepentingan mereka dan kepentingan masyarakat, maka perpisahan di antara mereka boleh dilakukan. ${ }^{5}$

Seandainya Islam tidak memberikan jalan menuju talak bagi suami istri dan tidak membolehkan mereka bercerai pada saat yang sangat kritis, niscaya hal itu akan membahayakan bagi pasangan tersebut. Mereka akan merasakan kehidupan rumah tangga

1 Departmen Agama RI., Al-Qur'an Dan Terjemahan, hlm. 552.

2 H. Amiur Nuruddin dan Azhari Akmal Trigan, Hukum Perdata Islam Di Indonesia Studi Kritis Perkembangan Hukum Islam Dari Fikih, UU No 1/ 1974 Sampai KHI (Kencana Prenada Group 2004), hlm. 206.

3 Khoiruddin Nasution, Hukum Perkawinan 1 (Tazzafa \& ACAdeMIA 2004), hlm. 56.

4 H. Aminur Nuruddin dan Azhari Akmal Tarigan, Hukum Perdata Islam Di Indonesia (Cet Ke-2, Pustaka Setia 2000), hlm. 208.

5 Rahmat Hakim, Hukum Perkawinan Islam (Cet Ke-2, Pustaka Setia 2000). 
mereka seperti neraka dan penjara yang berisi siksaan dan penderitaan. Hal itu pasti akan berakibat buruk terhadap anak-anak dan bahkan akan mempersulit kehidupan mereka. Karena, jika pasangan suami istri mengalami kegoncangan, maka anak-anak mereka pun pasti menderita dan menjadi korban. ${ }^{6}$

Jika diamati, aturan-aturan fikih berkenaan dengan talak, terkesan seolah-olah fikih memberi aturan yang longgar, bahkan dalam tingkat tertentu memberikan kekuasaan yang terlalu besar pada laki-laki. Seolah-olah talak menjadi hak prerogatif laki-laki, sehingga bisa saja seorang suami bertindak otoriter, misalnya menceraikan istri secara sepihak. ${ }^{7}$ Namun, Islam membuat hukum tidak dimaksudkan agar mereka terlena dan lupa, tetapi justru dibuat untuk menyembuhkan dan memperbaiki berbagai kesalahan manusia serta menyelamatkan mereka dari kejahatan yang sangat membahayakan dan kerusakan yang lebih fatal. Sedangkan dalam hukum positif kesannya memang mempersulit terjadinya perceraian antara suami dan istri dengan harapan dapat menekan tingginya angka perceraian. Salah satunya dengan adanya peraturan yang mengatur bahwa perceraian harus dilakukan dalam Pengadilan.

Pada zaman sekarang, permasalahan dalam keluarga Islam memerlukan satu penelitian yang mendalam. Hal ini karena kondisi kehancuran rumah tangga umat Islam di Negara ini yang semakin bertambah dari masa ke masa. Talak merupakan salah satu perkara yang terkandung dalam sistem perkawinan. Ia berlaku apabila terjadinya pergolakkan dalam rumah tangga yang tidak ada jalan penyelesaian baginya atau apabila terdapat pihak-pihak yang mengakhiri perkawinan. Allah S.W.T telah memerintahkan melalui beberapa firmanNya di dalam kitab suci Al-Quran agar suatu penceraian itu tidak membawa kemudaratan pada pihak yang lain terutama terhadap kebaikan anak-anak hasil perkawinan yang dibina sebelumnya. Sebagaimana Firman Allah S.W.T:

Talak (yang boleh dirujuk kembali itu hanya) dua kali. sesudah itu bolehlah ia (rujuk dan) memegang terus (isterinya itu) dengan cara yang sepatutnya atau melepaskan (menceraikannya) dengan cara yang baik." (Al-Baqarah: 229). ${ }^{8}$

Maksud menceraikan dengan baik (ma'ruf) adalah tidak dicerca dan tidak dilakukan kekerasan terhadap istri. Suami hendaklah menunaikan tanggungjawab apabila terjadi perceraian seperti memberi nafkah iddah dan nafkah anak, terutama menyangkut tentang hadhanah, pembagian harta dan sebagainya yang diselesaikan dengan cara bijaksana. Jika seorang suami tidak ada keperluan untuk menceraikan isterinya yaitu melafazkan talak tanpa alasan, ia boleh dianggap sebagai mengingkari nikmat Allah karena perkawinan dalam Islam adalah sebagian dari pada nikmat Allah S.W.T.

Di samping itu, untuk memastikan ruh dan semangat, talak dilakukan secara ma'ruf seperti yang diajarkan dalam Islam, maka Undang-Undang Keluarga Islam telah menentukan bahwa semua pemohonan talak hendaklah diajukan ke Mahkamah Syariah. Aturan tersebut dibuat berdasarkan kemaslahatan umum atas dasar Siyasah Syar'iyyah yang membenarkan suatu kerajaan membuat Undang-Undang, ini memberi gambaran bahwa undang-undang hanya mengakui perceraian yang berlaku di hadapan mahkamah syariah.

6 Syaikh Hasan Ayyub, Fikih Keluarga (Pustaka Al-Kausar 2006), hlm. 205-206. Beberapa penelitian menunjukkan bahwa terdapat pengaruh yang signifikan antara latar belakang keluarga broken home dengan perilaku anak, lihat lebih lanjut dalam Sukoco KW, Dino Rozano and Tri Utami, 'Pengaruh Broken Home terhadap Perilaku Agresif' [2016] Jurnal Penelitian Tindakan Bimbingan \& Konseling; Bandingkan dengan Melati Asmita Erny and Hidayati, 'Resiliensi Pada Anak Dari Keluarga Yang Broken Home'; Heryanto, 'Pembinaan Keluarga Broken Home' [2016] Jurnal Edueksos; Melissa Ribka Santi, Ferry Koagouw and Elfie Mingkid, 'Pola Komunikasi Anak-Anak Delinkuen Pada Keluarga Broken Home Di Kelurahan Karombasan Selatan Kecamatan Wanea Kota Manado' [2015] 'Acta Diurna'.

$7 \quad$ H. Aminur Nuruddin dan Azhari Akmal Tarigan (n 4), hlm. 214.

8 Departmen Agama RI. (n 1), hlm. 36. 
Persoalan talak di hadapan mahkamah di Negeri Selangor diatur dalam Enakmen Undang-Undang Keluarga Islam Negeri Selangor Tahun 2003. Talak sebagai bagian dari pada sistem perkawinan Islam yang telah diterima melalui hukum pembubaran perkawinan Islam dalam Undang-Undang Keluarga Islam Selangor dan diakui oleh sistem perundangan negara. Pengaturan dan pembubaran talak di Mahkamah Syariah ini dapat dilihat pada pasal 47. Dalam pasal ini, Enakmen menjelaskan tentang permohonan untuk perceraian kepada mahkamah, bagi suami atau istri yang ingin bercerai harus lebih dahulu mengajukan permohonan untuk bercerai kepada mahkamah dengan syarat yang ditetapkan, disertai dengan suatu pengakuan mengenai perceraian.

Sementara pada pasal 125 mengenai perceraian di luar mahkamah dan tanpa persetujuan mahkamah Syariah. "Jika seseorang laki-laki (suami) menceraikan istrinya dengan melafazkan talak dengan bentuk apa saja di luar mahkamah tanpa pengakuan mahkamah maka laki-laki itu adalah melakukan satu kesalahan (perbuatan itu) kepada Mahkamah, maka dia adalah melakukan sesuatu kesalahan dan hendaklah dikenakan sanksi tidak melebihi satu ribu ringgit atau dipenjara tidak melebihi selama 6 bulan atau keduanya sekali". ${ }^{9}$

Fenomena yang terjadi di Malaysia walaupun aturan Undang-Undang telah ditentukan namun, kenyataan yang terjadi dalam masyarakat, talak di luar mahkamah sering terjadi. Berdasarkan statistik jumlah perceraian di Selangor yang dilaporkan oleh Jabatan Kehakiman Syariah Selangor mencatat angka paling tinggi dalam perceraian sebanyak 22,230 kasus dalam tegang waktu tiga tahun berturut sejak tahun 2013 sehingga 2015. ${ }^{10}$ Pada umumnya, ia dimulai apabila terjadinya perselisihan dan di luar batas, suami akan melafazkan talak terhadap istri. Kebanyakan yang dicerai di luar mahkamah akan ditinggal oleh suami, jika terjadi seperti itu pihak istri sukar untuk membuktikan perceraian yang terjadi ke mahkamah, apabila pihak suami tidak memberi kerjasama. ${ }^{11}$

Berdasarkan pembahasan di atas, artikel ini ditulis dengan judul: "Efektivitas Pelaksanaan Sanksi Talak Di Luar Mahkamah (Studi Kasus Di Mahkamah Rendah Syariah Selangor)."

\section{Pengertian Talak}

Talak merupakan pemutusan tali perkawinan. Talak ini merupakan suatu yang disyariatkan. Dan menjadi dasarnya adalah al-Quran dan al-Hadits serta Ijma'. ${ }^{12}$ Kata talak dalam bahasa Indonesia merupakan satu kata asing yang telah diserap dan dibakukan. Asalnya dari bahasa Arab, yaitu țalaq, țalqan, țallāqan, maknanya ațlaq imra'atih, yaitu mentalak, menceraikan, melepaskan, membebaskan, membuka, atau mengu-mumkan. ${ }^{13}$

Yahya Abdurrahman al-Khatib menyatakan kata talak (istilah yang digunakan yaitu tāliq) secara bahasa adalah unta yang tali kekangnya diuraikan dan dia dilepaskan di tempat pengembalaan. Ibn Munzir, sebagaimana dikutip oleh al-Khatib, menyebutkan bahwa menalak wanita memiliki dua makna, yaitu: (1) menguraikan ikatan perkawinan, (2)

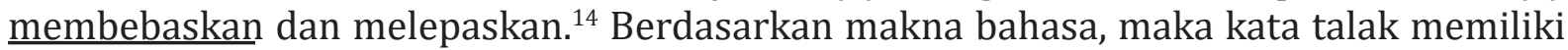

9 'Enakmen 2 Tahun 2003, Enakmen Undang-Undang, Pentadbiran Keluarga Islam Pasal No 125, Tentang Perceraian Di Luar Mahkamah Dan Tanpa Kebenaran Mahkamah, Bahagian Kesalahan Dan Hukuman.'

Jabatan Kehakiman Selangor, 'Statistik Perceraian Negeri Selangor' <Selangor.Kehakiman.gov.my> accessed 10 June 2017.

11 Mohd Naim Hj. Mokhtar, Talak: Konsep Dan Perlaksanaan Di Mahkamah Syariah (Dewan Pustaka 2003), hlm. 140.

12 Syaikh Hasan Ayyub (n 6), hlm. 207

13 Achmad Warson Munawwir dan Muhammad Fairuz, Al-Munawwir: Kamus Indonesia Arab (Pustaka Progressif 2007), hlm. 861.

14 Yahya Abdurrahman al-Khatib, Fikih Wanita Hamil (Ạ̣kām Al-Mar'ah Al-Ḥāmil Fī Al-Syarīah Al- 
beberapa makna, bisa melepaskan, membuka, atau menceraikan. Namun, dalam artikel ini hanya difokuskan pada makna menceraikan. Sementara untuk makna melepaskan diarahkan pada melepaskan tali pernikahan.

Menurut terminologi, banyak ditemukan definisi yang dirumuskan oleh para ulama. Redaksi yang digunakan juga berbeda-beda, tetapi tujuannya sama yaitu memutuskan perkawinan dengan menggunakan lafal talak. Menurut empat imam mazhab, sebagaimana disebutkan oleh al-Baghawī, yaitu:

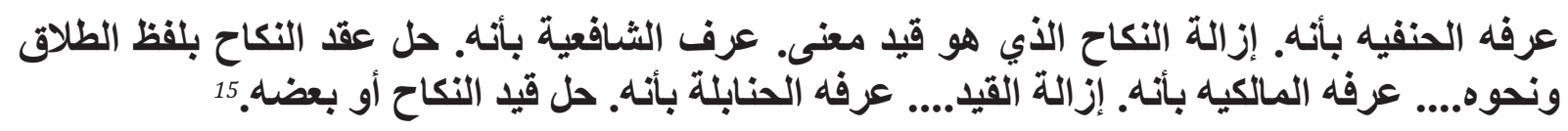

Pengertian (talak) dalam mazhab Hanafiyahyaitu menghilangkan ikatan pernikahan yang berarti hanya menghilakan ikatan. Pengertian (talak) dalam mazhab Syafi'iyyah yaitu melepas tali perkawinan dengan menggunakan lafal talak atau sejenisnya. Pengertian (talak) dalam mazhab Malikiyah yaitu menghilangan dan melepasakan (ikatan perkawinan). Pengertian (talak) dalam mazhab Hanabillah yaitu melepaskan tali perkawinan (secara keseluruhan) atau sebagiannya.

Redaksi yang digunakan masing-masinga mazhab tampak berbeda, tetapa pada dasarnya memiliki makna yang sama, yaitu talak dimaknai sebagai pemutusan tali pernikahan. dalam pengertian lainnya, al-Jazīrī menyatakan talak yaitu:

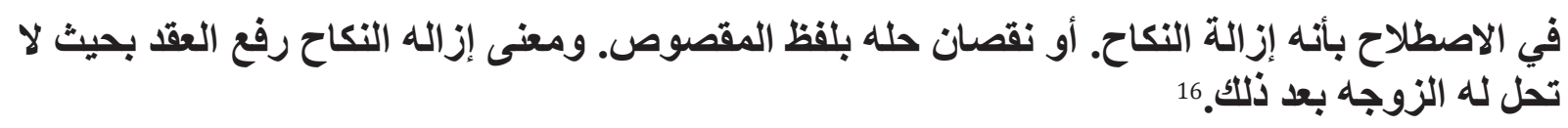

Secara istilah bahwa (talak yaitu) menghilangkan ikatan perkawinan atau mengurangi pelepasan ikatannya dengan menggunakan kata-kata atau lafal yang khusus. Berarti menghilangkan ikatan perkawinan melalui pemutusan akad sehingga tidak halal lagi baginya isteri setelah pemutusan tersebut.

Rumusan ini tampak lebih komprehensif dari rumusan sebelumnya, di mana konsekuensi dari talak juga disebutkan secara tegas, yaitu isteri tidal halal lagi bagi suaminya. Berbeda dengan rumusan di atas, Muhammad Abū Zahrah menyatakan:

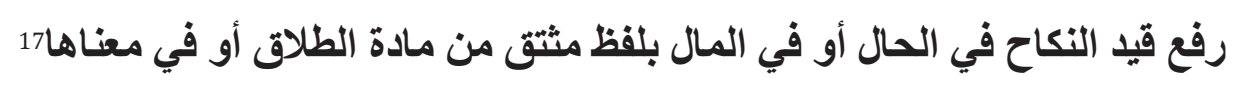

Menghilangkan ikatan perkawinan pada waktu itu atau waktu yang akan datang dengan menggunakan lafaz tertentu dari kata talak atau lafal yang semakna.

Pengertian di atas menunjukkan bahwa terputusnya tali nikah tidak hanya berlaku pada saat talak itu dijatuhkan, tetapi pemutusan itu bisa saja dilakukan pada waktu yang akan datang, misalnya dengan menyatakan, "jika kamu keluar rumah nanti, maka kamu akan tertalak". Talak jenis ini oleh jumhur ulama diperkenankan dan dibolehkan. Syuhabuddin al-Ramlī mendefinisikan talak secara singkat, yaitu:

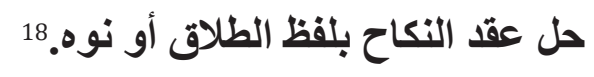

Melepas tali akad nikah dengan kata talak dan yang semacamnya.

15 Imam Abī Muḥammad al-Ḥusain bin Mas'ūd bin Muḥammad bin al-Farrā' al-Baghawī, Al-Tahżīb Fī Fiqh Al-Imām Al-Syāfi'ī (Juz 6, Dār al-Kutub al-'Ulimiyyah 1997), hlm. 4.

16 'Abd al-Rāḥmān al-Jazīrī, Kitāb Al-Fiqh 'Alā Al-Mażāhib Al-Arba'Ah (Juz 5, Dār al-Kutb al-'Ilimiyyah 2003), hlm. 248.

17 Al-Imām Muhammad Abū Zahrah, Al-Aḥwāl Al-Syakhșiyyah (Dār al-Fikr al-'Arabī 1948), hlm. 279.

18 Syihāb al-Dīn Abī al-'Abbās Ahmad bin Ahmad bin Ḥamzah al-Ramlī, Fatḥ Al-Raḥmān Bi Syarh Zubad Ibn Ruslān (Dār al-Minhāj li al-Nasyr wa al-Taizì' 2009), hlm. 783. 
Beberapa rumusan di atas memiliki redaksi yang berbeda, namun intinya adalah menceraikan isteri dengan menggunakan lafal tertentu. Ibnu Qudamah memberi makna talak sangat singkat, yaitu "ḥallu qiyadu al-nikāḥ",19 artinya, "melepaskan ikatan perkawinan". Definisi lainnya dapat dipahami dari pengertian yang disebutkan oleh alJazairi, di mana talak merupakan terurainya ikatan tali pernikahan dengan perkataan yang jelas, seperti perkataan suami, "engkau aku ceraikan", atau dengan bahasa sindiran yang disertai niat perceraian seperti suami berkata kepada isterinya, "pergilah kepada keluargamu". ${ }^{20}$ Jadi, talak memiliki makna suatu perkatataan yang diucapkan oleh pihak suami terhadap isteri yang tujuannya adalah memutuskan ikatan perkawinan. Berdasarkan uraian di atas, dapat dinyatakan bahwa talak adalah perkataan suami terhadap isteri, baik secara jelas maupun secara kiasan untuk memutuskan perkawinan dengan menggunakan lafal talak, atau lafal lainnya yang memiliki makna yang sama dengan talak. Terjadinya talak akan mengakibatkan isteri tidak halal lagi bagi suami sesaat setelah lafal talak itu diucapkan.

\section{Dasar Hukum Talak}

Hukum asal talak adalah dibolehkan. Hal ini berdasarkan beberapa dalil yang menunjukkan tentang kebolehannya. ${ }^{21}$ Sifat kebolehan talak ini lantaran bisa saja kondisi hubungan antara suami isteri telah rusak, sehingga dipeliharanya ikatan suami isteri hanya sematamata menjadi sebuah kerusakan dan keburukan. ${ }^{22}$ Atas dasar ini, suami bisa menceraikan isterinya, sebab dengan jalan talak inilah kerusakan yang kemungkinana lebih besar ditimbulkan akan dapat dihindari. Al-Sabuni menyebutkan, tidak jarang rumah tangga mengalami badan dan angin yang sangat kencang (perpecahan). Dalam hal ini, Islam telah mengatur prosedurnya sebelum terjadi perpisahan, yaitu dengan adanya juru damai atau hakam. ${ }^{23}$ Satria Effendi menyebutkan pada kondisi tertentu, perceraian terpaksa difungsikan karena hanya dengan itu suatu percekcokan bisa diakhiri. ${ }^{24}$ Dengan demikian, jika langkah-langkah yang dijelaskan dalam Alquran dan hadis tidak terlaksana dengan baik, maka langkah perceraian bisa diambil oleh suami.

Terdapat banyak dalil pensyariatan talak, baik dalam Alquran maupun hadis Rasulullah SAW. Di antara ayat Alquran yang mensyariatkan talak adalah surat al-Ṭalāq ayat 1:

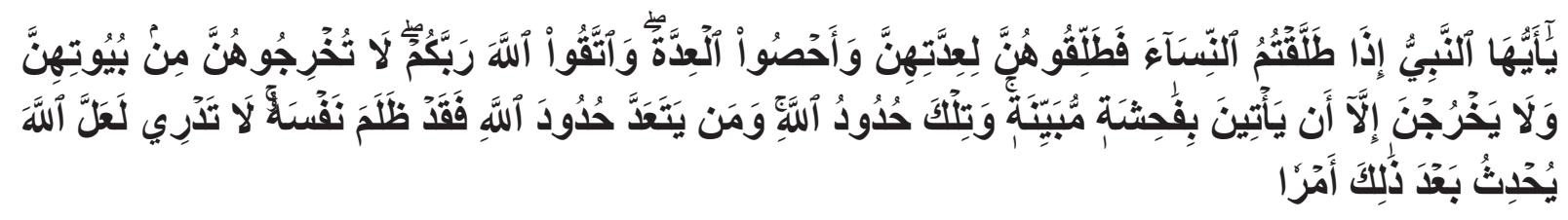

Hai Nabi, apabila kamu menceraikan isteri-isterimu maka hendaklah kamu ceraikan mereka pada waktu mereka dapat (menghadapi) iddahnya (yang wajar) dan hitunglah waktu iddah itu serta bertakwalah kepada Allah Tuhanmu. janganlah kamu keluarkan mereka dari rumah mereka dan janganlah mereka (diizinkan) ke

19 Al-Imām al-'Allāmah Muwaffiq al-Dīn Abī Muḥammad 'Abdullāh bin Aḥmad bin Maḥmūd bin Qudāmah, Al-Mughnī Al-Syarh Al-Kabìr (Juz 8, Dār al-Kutub al-'Arabī), hlm. 233.

20 Minhāj al-Muslim Abu Bakar Jabir al-Jazairi, Minhajul Muslim: Pedoman Hidup Seorang Muslim (Ummul Qura 2014), hlm. 837.

21 Al-Habīb Țāhir, Al-Fiqh Al-Mālikī Wa Adillatuh (Mu'assasah al-Ma'ārif 2005), hlm. 24.

22 Wahbah al-Zuhaili, Fiqh Islam: Pernikahan, Talak, Khulu', Meng-Ila' Isteri, Li'an, Zihar, Masa Iddah (Jilid 9, Gema Insani Press 2011), hlm. 319; Talak adalah hak suami. Pertimbangannya bahwa laki-laki lebih mampu berfikir dan mempertimbangkan kelangsungan keluarga. Lihat dalam A. Hamid Sarong, Hukum Perkawinan Islam Di Indonesia (Yayasan PeNA 2010), hlm. 122.

23 Muhammad Ali al-Sabuni, Hadiah Untuk Pengantin (Hadiyyah Al-'Afrah Li Al-'Arūsain Al-Zawāj AlIslām Al-Mubakkir: Sa'Ādah Wa Hasānah) (Mustaqim 2004), hlm. 331.

24 Satria Effendi M. Zein, Problematika Hukum Keluarga Islam Kontemporer: Analisis Yurisprudensi Dengan Pendekatan Ushuliyah (Kencana Prenada Group 2010), hlm. 50. 
luar kecuali mereka mengerjakan perbuatan keji yang terang. Itulah hukum-hukum Allah, Maka Sesungguhnya Dia telah berbuat zalim terhadap dirinya sendiri. kamu tidak mengetahui barangkali Allah Mengadakan sesudah itu sesuatu hal yang baru. (QS. al-Ṭalāq: 1).

Selain itu, diperoleh juga ketentuan dalam surat al-Baqarah ayat 229, yaitu sebagai berikut: ${ }^{25}$

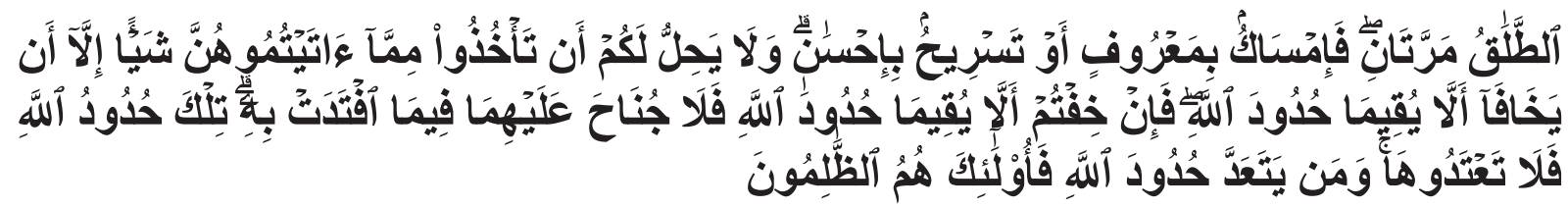

Talak (yang dapat dirujuki) dua kali. setelah itu boleh rujuk lagi dengan cara yang ma'ruf atau menceraikan dengan cara yang baik. tidak halal bagi kamu mengambil kembali sesuatu dari yang telah kamu berikan kepada mereka, kecuali kalau keduanya khawatir tidak akan dapat menjalankan hukum-hukum Allah. jika kamu khawatir bahwa keduanya (suami isteri) tidak dapat menjalankan hukum-hukum Allah, Maka tidak ada dosa atas keduanya tentang bayaran yang diberikan oleh isteri untuk menebus dirinya. Itulah hukum-hukum Allah, Maka janganlah kamu melanggarnya. Barangsiapa yang melanggar hukum-hukum Allah mereka Itulah orang-orang yang zalim. (QS. Al-Baqarah: 229).

Dua ayat di atas setidaknya mewakili dari sekian banyak dalil-dalil tentang talak. Intinya, talak diperkenankan dalam Islam jika kondisi rumah tangga tidak dimungkinkan lagi untuk disatukan, baik disebabkan oleh berbedanya karakter masing-masing pihak, adanya cacat dari pihak isteri yang berakibat suami enggan melaksanakan kewajiban, dan adanya pertengakaran secara terus menerus yang susah untuk didamaikan. Selain itu, dalam dalil hadis juga ditemukan keterangan bolehnya menceraikan isteri, di antaranya adalah hadis riwayat Bukhari dari Yahya bin Bukair sebagai berikut:

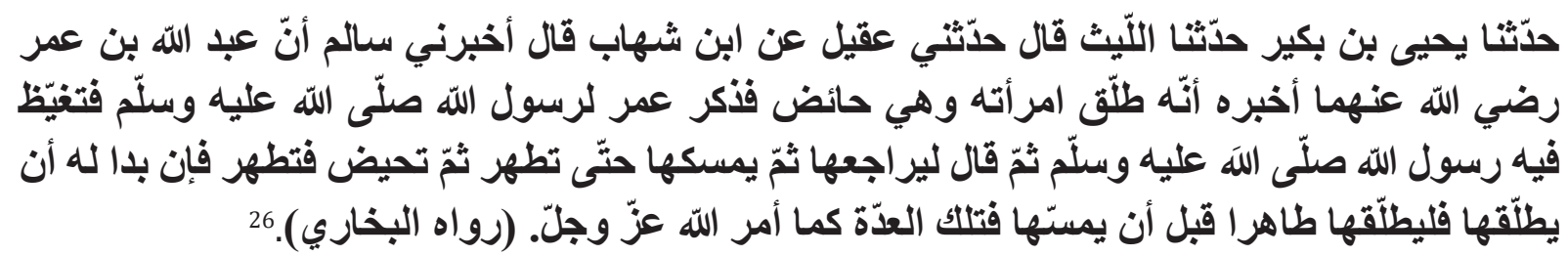

Telah menceritakan kepada kami Yahya bin Bukair Telah menceritakan kepada kami Al Laits ia berkata, Telah menceritakan kepadaku 'Uqail dari Ibnu Syihab ia berkata, Telah mengabarkan kepadaku Salim bahwa Abdullah bin Umar radliallahu 'anhuma Telah mengabarkan kepadanya; Bahawasanya ia pernah mentalak isterinya dalam keadaan haidl. Maka Umar pun menyampaikan hal itu pada Rasulullah shallallahu 'alaihi wasallam. Maka Rasulullah shallallahu 'alaihi wasallam marah dan bersabda: "Hendaklah ia meruju'nya kembali, lalu menahannya hingga ia suci dan haidl hingga ia suci kembali. Bila ia (Ibnu Umar) mau menceraikannya, maka ia boleh mentalaknya dalam keadaan suci sebelum ia menggaulinya. Itulah Al 'Iddah sebagaimana yang telah diperintahkan Allah 'azza wajalla. (HR. Bukhari).

Dalam riwayat Abu Daud, dari Katsir bin 'Ubaid juga disebutkan bahwa talak merupakan hal perkara yang dihalalkan dalam agama Islam, tetapi dibenci oleh Allah:

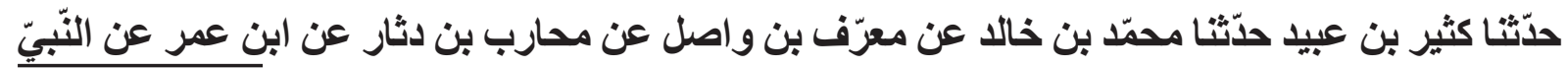

25 Abdul Aziz Muhammad Azzam dan Abdul Wahhab Sayyid Hawwas, Fiqh Munakahat (Al-Usrah Wa Ahkāmuhā Fì Li Al-Tasyrī’ Al-Islāmī) (Amzah 2011), hlm. 256.

26 Imām al-Ḥāiz Abī 'Abdillāh Muhammad bin Ismā'īl al-Bukhārī, Ṣaḥịhal-Bukhārī (Bait al-Afkār alDauliyyah Linnasyr 1998), hlm. 1018. 


$$
\text { صلّى الله عليه وسلّم قال أبغض الحلال إلى اللّ تعالى الظّلاق. (رواه ابو داود).27 }
$$

Telah menceritakan kepada kami Katsir bin 'Ubaid, telah menceritakan kepada kami Muhammad bin Khalid dari Mu'arrif bin Washil dari Muharib bin Ditsar dari Ibnu Abbas dari Nabi shallallahu 'alaihi wasallam beliau bersabda: "Perkara halal yang paling Allah benci adalah perceraian. (HR. Abu Daud).

Berdasarkan beberapa dalil di atas, jelas bahwa talak diperkenankan dalam Islam. umat muslim telah berkonsensus atau berijma' atas pembolehan talak. ${ }^{28} \mathrm{Hal}$ ini juga didukung oleh logika di mana saat hubugan suami isteri sudah retak, maka pilihannya ada dua, memutuskan (dengan jalan talak) atau merajut kembali. Dengan demikian, dapat disimpulkan bahwa talak dalam Islam memiliki dasar hukum yang jelas dan hukumnya dibolehkan. Suami sebagai pihak yang dapat menilai apakah hubungan perkawinan harus berakhir atau tidak. Kondisi-kondisi tertentu dapat menjadi alasan talak dapat dilakukan oleh suami.

\section{Rukun dan Syarat Talak}

Ulama masih berbeda dalam menetapkan rukun talak. Mazhab Hanafi berpendapat rukun talak adalah lafal yang menjadi dilälah bagi makna talak secara bahasa yang merupakan pelepasan dan pengiriman. Artinya, rukun talak hanya satu, yaitu lafal talak itu sendiri. Sedangkan mazhab maliki, rukun talak ada empat, yaitu "mampu melakukannya". Maksudnya orang atau pihak yang menjatuhkannya yaitu suami, atau wakilnya, atau walinya jika dia masih kecil. "Maksud", yaitu ucapan dengan lafal yang terang-terangan, dan sindiran yang jelas, meskipun tidak bermaksud melepaskan ikatan perkawinan. Dengan dalil sahnya talak yang dilakukan secara bergurau. Objek, maksudnya perkawinan yang dia miliki. Rukun terakir yaitu "lafal" yang secara jelas-jelasan ataupun secara sindiran. Mazhab Syafi'i dan mazhab Hambali berpendapat, rukun talak ada lima, yaitu laki-laki yang mentalak, ucapan, objek, kekuasaan, dan maksud. ${ }^{29}$

'Abd al-Rāḥmān al-Jazīrī menyebutkan rukun talak ada empat, yaitu suami, isteri, lafal talak, dan qașdu (maksud menceraikan). ${ }^{30}$ Dalam hal ini jelas bahwa ulama masih berbeda dalam menetapkan rukun talak, tetapi intinya sama, bahwa dalam mentalak itu harus ada empat unsur sperti disebutkan al-Jazīrī, yaitu suami yang menceraikan, isteri yang diceraikan, lafal talak, dan qașdu atau maksud suami menceraikan. Meskipun dalam mazhab Hanafi hanya menyebutkan lafal talak saja, tetapi suami, isteri dan maksud juga dibutuhkan mengiringinya. Lafal talak tidak ada kecuali tidak ada suami yang mengucapkannya. Ucapan talak juga tidak akan ada dan tidak memiliki pengaruh apa-apa jika tidak ada isteri yang diceraikan, demikian juga dengan maksud dan niat untuk menceraikan. Dengan demikian, perbedaan pendapat tersebut sebenarnya tidak pada substansinya.

Adapun syarat talak yaitu berkaitan dengan syarat-syarat yang harus dipenuhi dalam unsur-unsur talak. Abu Malik menyatakan, syarat talak diperlukan untuk keabsahan talak. ${ }^{31}$ Dalam hal ini syarat yang dimaksudkan yaitu yang harus terpenuhi bagi pihak yang menceraikan, pihak yang diceraikan, lafal dan maksud talak.Suami yang menceraikan disyaratakan berakal, baligh, dan atas kemauan sendiri. Bagi isteri yang diceraikan,

$\overline{27}$ Abī Dāwud Sulaimān bin al-Asy'aṡ al-Sajastānī, Sunan Abī Dāwud (Bait al-Afkār al-Dauliyyah Linnasyr); Ibnu Qayyim al-Jauziyyah, Tahżīb Al-Sunan Li Imām Ibn Qayyim (Maktabah al-Ma'ārif li al-Nasyr wa al-Tauzī' 2007).

28 Wahbah Al-Zuhailī, Al-Fiqh Al-Islāmī Wa Adillatuh (Dār al-Fikr 1985), hlm. 319.

29 Ibid., hlm. 322.

30 'Abd al-Rāḥmān al-Jazīīi (n 16), hlm. 249-251.

31 Abu Malik Kamal bin al-Sayyid Salim, Fiqih Sunnah Wanita: Panduan Lengkap Wanita Muslimah (Fiqh Al-Sunnah Lin Nisā: Wa Mā Yajibu an Ta'rifuh Kulli Muslimah Min Aḥkām) (Griya Ilmu Mandiri Sejahtera 2016), hlm. 616. 
disyaratakan harus wanita yang menjadi isteri yang sah dan masih berada dalam perlindungan suami. Sighat atau lafal talak disyaratkan bahwa harus sebagai ungkapan yang memiliki maksud cerai, baik ungkapan tersebut jelas maupun sindiran. ${ }^{32}$

Kemudian lafal talak bisa juga dalam bentuk isyarat bagi suami yang tuna wicara, dan bisa juga dengan tulisan. Talak tidak berlaku ketika dengan perbuatan memukul, mengantarkan isteri ke rumah keluarganya atau menyerahkan barang-barangnya. Adapun syarat yang harus dipenuhi dalam qașdu (maksud menceraikan) adalah dengan ucapan ataupun tulisan memang memiliki maksud menceraikan isteri dan tidak dimaknai lain. Oleh karena itu, salah ucap tanpa sengaja, tidak berlaku talak. ${ }^{33}$ Setelah dipenuhi syarat dan rukun di atas, maka talak seorang suami telah dipandang sah secara agama.

Terkait dengan lafal talak, al-Subki menyetakan, bagi orang yang berniat dalam dirinya mentalak isterinya dan tidak diucapkan dengan talak, maka talaknya tidak terjadi. ${ }^{34}$ Artinya, ucapan ataupun tulisan yang menunjukkan makna perceraian harus dapat diketahui oleh pihak isteri, baik dalam bentuk sindiran atau secara jelas. Untuk itu, talak tidak bisa hanya sekedar niat saja, meskipun suami memiliki niat dan keinginan untuk cerai.

\section{Hikmah Pensyari'atan Talak}

Setiap syariat yang diberlakukan oleh Allah memiliki hikmah dan tujuan tersendiri. Imam al-Syāțibī dalam kitabnya, al-Muwāfaqāt fì Ușūl al-Syarī’ah, menyatakan bahwa dibebankannya hukum syari'ah dikembalikan untuk menjaga tujuan-tajuannya. ${ }^{35}$ Dalam keadaan adanya tujuan dan maksud syari'at itu, maka tujuan dari setiap hukum adalah agar tercapainya kemaslahatan dan terhindarnya kemudharatan. Bahkan kemaslahatan itulah yang menjadi dasar pembentukan hukum Islam. Al-Khallaf menyebutkan tujuan umum pensyariatan hukum Islam adalah untuk menciptakan kemaslahatan manusia dan mengilangkan kemudharatan. ${ }^{36}$ Dalam kaidah fikih disebutkan:

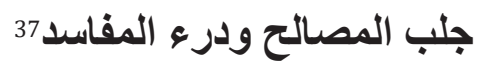

"Mendatangkah kemaslahatan dan menghilangkan kemudharatan."

Terkaitdengan hikmah dantujuan disyariatkan talak,cukupjelasyaitu untukmendatangkan kemaslahatan bagi pasangan suami isteri dan menghilangkan kemudharatan yang akan ditimbulkan ketika perkawinan tetap dipertahankan.Cukup banyak hikmah diberlakukannya talak dalam Islam. Ibnu Sina dalam kitab al-Syifa', sebagaimana dikutip oleh Sayyid Sabiq, menyatakan bahwa seharusnya jalan cerai itu diberikan dan jangan ditutup sama sekali karena menutup mati jalan perceraian akan mengakibatkan beberapa bahaya dan kerusakan. ${ }^{38}$ Putusnya perkawinan adalah sesuai yang wajar, kerana makna dasar sebuah akad nikah adalah ikatan atau kontrak. ${ }^{39}$ Atas dasar itulah, perceraian adalah hal yang mungkin terjadi terhadap satu pasangan nikah. Talak sebagai jalan untuk mengindari kemudharatan bagi pasangan suami isteri. Untuk itu, Islam membolehkan dan mensyari'atkan talak, dan suami bisamenggunakan hak talaknya. Hal ini sesuai dengan pernyataan Ibnu Taimiyah, bahwa syariat itu diturunkan untuk menghilangkan mafāsid

\footnotetext{
32 Abdu Rahman Ghazaly, Fiqh Munakahat (Kencana Prenada Media Group 2006), hlm. 202-205.

33 Ibid.

34 Ali Yusuf al-Subki, Fiqh Keluarga (Nizām Al-Usrah Fī Al-Islām) (Amzah 2010), hlm. 333.

35 Abī Ishāa al-Syāțibī Ibrāhīm bin Mūsā al-Lakhmī al-Gharnāțī al-Mālikī, Al-Muwāfaqāt Fī Ușūl AlSyarīah (Dār al-Kutub al-'Ulumiyyah 2004), hlm. 221.

36 Abd al-Wahhāb al-Khallāf, 'Ilm Al-Ușūl Al-Fiqh (Maktabah al-Da'wah al-Islamiyyah 1947), hlm. 197.

37 Abī Muḥammad 'Izz al-Dīn 'Abd al-'Azīz bin 'Abd al-Salām al-Salamī, Qawā'id Al-Aḥkām Fī Mașāliḥ AlAnām (Maktabah Kulliyyāt al-Azhariyyah 1994), hlm. 17.

38 Sayyid Sabiq, Fiqh Al-Sunnah, Jilid 3, (Pena Pundi Aksara 2006), hlm. 138.

39 H. Amiur Nuruddin dan Azhari Akmal Trigan (n 2), hlm. 206.
} 
atau kemudharatan, atau paling tidak mengecilkan kemudharatan yang ada. ${ }^{40}$

Berdasarkanuraiandiatas, hikmah ditetapkannyahukumtalakadalahuntukmenghilangkan beban bagi kedua pasangan ketika masih bersatu yang justru memudharatkan bagi kedua pihak. Dengan jalan talak, maka kemungkinan-kemungkinan mudharat, seperti efek dari emosi yang berlebihan dapat dihindari.

\section{Hasil Penelitian: Efektivitas Pelaksanaan Sanksi Talak di Luar Mahkamah Rendah Syariah Selangor, Malaysia. ${ }^{41}$ \\ Prosuder Menjatuhkan Talak Menurut Enakmen Negeri Selangor}

Penjatuhan talak diakui legalitasnya dalam Undang Undang keluarga Islam Selangor dan diakaui oleh sistem Perundangan Negara. Pengaturan talak di depan mahkamah syariah dilihat pada pasal 40 (1) serta pasal 126 (1).

Barang siapa yang berkewajiban membuat sesuatu laporan dibawah Enakmen ini dengan sengaja lalai atau tidak berbuat demikian adalah melakukan sesuatu kesalahan dan apabila hukuman telah dijatuhkan maka boleh dikenakana sanksi tidak melebihi satu ribu ringgit atau dipenjarakan selamamasa tidak melebihi enam bulan atau kedua-duanya.

Dalam Enakmen ini, juga dijelaskan tentang syarat-syarat penjatuhan talak. Pihak yang ingin menjatuhkan talak diharuskan membuat laporan termasuk permohonan untuk perceraian kepada mahkamah. Laporan yang dibuat dapat membantu penyelesaian kasus yang terjadi. Seksyen 47 angka (1) telah menetapkan bahwa: "Seorang suami atau isteri yang hendak bercerai hendaklah menyerahkan suatu permohonan untuk perceraian kepada Mahkamah dalam formulir yang ditetapkan disertai dengan suatu keterangan yang mengandung beberapa butiran:

1. Butiran perihal tentang perkawinan baik dari nama, umur, jenis kelamin anak-anak (jika ada) dari perkawinan itu.

2. Butiran-butiran mengenai fakta-fakta memberi bidang kuasa pada pihak mahkamah di bawah seksyen 45 .

3. Butiran-butiran mengenai prosiding yang terdahulu mengenai hal ehwal suami isteri antara pihak pihak itu, termasuk tempat prosiding itu.

4. Suatu penyataan tentang sebab hendak bercerai.

5. Suatu penyataan tentang langkah-langkah yang telah diambil untuk mencapai perdamaian.

6. Syarat-syarat dan apa -apa perjanjian berkenaan dengan nafkah dan tempat kediaman bagi isteri dan anak-anak dari perkawinan itu jika ada, peruntukkan bagi pemeliharaan dan penjagaan anak-anak daripada perkawinan itu, jika ada, apaapa aset daripada usaha bersama pihak-pihak itu.

7. Butiran mengenai perintah yang diminta.

Berdasarkan penjelasan sebelumnya, dapat diketahui bawha suami isteri yang ingin bercerai harus terlebih dahulu mengajukan permohonan untuk bercerai kepada Mahakamah dalam formulir yang disertai dengan suatu keterangan mengenai perceraian.

40 Syaikh al-Islām al-Imām al-Allāmah Taqī al-Dīn Ibn Taimiyah, Syarh Kitāb Al-Siyāsah Al-Syar'iyyah (Pensyarah: Muhamman bin Șālih al-'Uṡaimīn, Dār ibn Hazm 2004), hlm. 151.

41 Lokasi penelitian penulisan artikel ini adalah Mahkamah Rendah Syariah Selangor, khususnya di Mahkamah Rendah Syariah Gombak Barat telah ada sejak tahun 1980, saat itu dibina oleh pihak Jabatan Agama Selangor. Mahkamah Rendah Syariah Selangor berlokasi di Batu 17 3/4, 48050 kuang, Selangor Darul Ehsan.Mahkamah Syariah pada masa silam belum memiliki sistem seperti sekarang ini. 
Sementara itu, terkait perceraian di luar mahkamah dan tanpa persetujuan mahkamah, maka si suami dipandang telah melakukan kesalahan. Meski demikian, Enakmen tersebut menegaskan dalam masa 7 hari setelah dilafalkan talak, hendaklah segera melaporkan perceraian itu kepada mahkamah. Perbuatan itu merupakan satu kesalahan dan akan dihukum sanksi tidak melebihi satu ribu ringgit (RM 1000) atau (Rp. 3,000.000) atau tidak melebihi enam bulan penjara atau kedua-duanya. Perkara ini jelas dalam enakmen 125 Undang-Undang Keluarga Islam Selangor yaitu:

Jika seorang lelaki (suami) menceraikan isterinya di luar mahkamah tanpa pengakuan mahkamah maka lelaki itu sudah melakukan kesalahan akan dikenakan sanksi tidak membayar sejumlah tidak melebihi satu ribu ringgit (Rp. 3.000.000) dan penjara tidak melebihi enam bulan atau kedua-duannya.

Berdasarkan hal tersebut, dapat diketahui bawha setiap rakyat Malaysia terutama di Negeri Selangor, Seharusnya memenuhi setiap tuntutan hukum yang berlaku ketika ingin melakukan perceraian, walaupun keinginan talak tersebut terjadi sebelum atau di luar mahkamah. Ini menunjukkan keperhatinan pihak pemerintah terhadap masalah yang berkaitan dengan institusi kekeluargaan, baik dari segi pernikahan dan juga perceraian. Aturan selanjutnya bahwa keharusan bagi pihak isti untuk emmebuat laporan perceraian. Jika pihak isteri yang menerima talak tidak membuat laporan kepada mahkamah, maka ia akan ditetapkan sebagai satu kesalahan menurut Enakmen Keluarga Islam Selangor (2003), seksyen 126 (2) yang berbunyi:

Barang siapayang berkewajiban membuatlaporan atau dikehendaki mengemukakan sesuatu permohonan di bawah Enakmen ini atau dikehendaki memberi apa-apa maklumat atau menyempurnakan atau menandatangani apa-apa dokumen yang perlu di sisi Undang-Undang bagi melaksanakan pendaftaran dokumen itu dengan sengaja lalai atau tidak membuat laporan atau tidak mematuhi peraturan itu ia merupakan suatu kesalahan dan apabila didapati bersalah boleh dihukum sanksi.

Dengan ini menunjukkan bahwa, Malaysia sangat menitikberatkan kepada kedua pasangan agar keinginan untuk bercerai harus disertakan formulir dan harus nelaporkan ke pihak mahkamah. Formulir keinginan bercerai tersebut diberikan kepada Ketua Pendaftar Cerai serta mengikuti prosuder-prosuder yang sudah ditetapkan oleh Undang-Undang Kerajaan Negeri Selangor. Meski aturan tegas tentang syarat-syarat perceraian telah ada, tetapi talak di luar mahkamah tetap saja dilakukan. Untuk itu, pemerintah akan memberikan sanski bagi pelaku. Pembahasan tentang faktor pelaksanaan sanksi talak di Mahkamah Rendah Syaroah Selangor akan dikemukakan dalam sub bahasan tersendiri di bawah ini.

\section{Faktor-Faktor yang Mempengaruhi Pelaksanaan Sanksi Talak di Luar Mahkamah Rendah Syariah Selangor}

Mengawali sub bahasan ini, penting dikemukakan bahwa perceraian (talak) merupakan jalan terakhir bagi satu pasangan untuk mengakhiri hubungan pernikahan yang telah lama atau baru saja dibina. Islam mensyariatkan talak tidak lain sebagai jalan alternatif terkahir untuk menyelesaikan kegaduhan hubungan rumah tangga. Atas dasar syariat tersebut, suami mempunyai hak untuk memutuskan tali nikah dengan jalan talak. ${ }^{42}$ Meskipun disyariatkan, terdapat beberapa aturan yang bersifat formal, di mana talak yang harusnya dilakukan di Mahkamah/Pengadilan justru dilakukan di luar Mahkamah. Hal ini

42 Ibnu Qayyim menyebutkan talak merupakan hak suami demikian merujuk isterinya. Lihat dalam Syams al-Dīn Abī 'Abdillāh Muḥammad bin Abī Bakr al-Zar'ī Ibn Qayyim al-Jauziyyah, Zād Al-Ma'ād F̄̄ Hadī Khair Al-'Ibād (Juz 5, Mu'assasah al-Risālah 1998), hlm. 185. 
menjadi polemik tersendiri dalam penanganan kasus-kasus perceraian dewasa ini.

Perceraian atau talak di luar Mahkamah sering sekali ditemukan di lapangan, khususnya pada masyarakat Selangor. Tuan Abdul Hadi, selaku Hakim II pada Mahkamah Rendah Syariah Selangor menyebutkan, di Malaysia pada umumnya memandang talak di luar mahkamah tetap sah secara hukum syara', akan tetapi ada kewajiban bagi suami yang menjatuhkan talak untuk memberitahukan kepada pihak Mahkamah dalam tempo 7 (tujuh) hari setelah lafaz talak diucapkan. Hal ini menurut Hakim II Mahkamah Rendah Syariah Selangor dilakukan agar talak yang diucapkan dapat diproses secara hukum dan mendapat pengesahan dari pihak mahkamah. ${ }^{43}$ Adapun transkrip hasil wawancara tersebut adalah:

Di Malaysia Talak di luar mahkamah itu masih sah tetapi setelah itu dalamtempoh 7 (tujuh) hari selepas lafaz cerai dijatuhkan harus melaporkan kepada mahkamah bagi mengesahkan secara legal oleh pihak hakim. ${ }^{44}$

Kutipan di atas memberi makna umum bahwa sah tidaknya talak mengacu pada ketentuan hukum Islam. Artinya, dalam Islam tidak ditentukan penjatuhan talak di tempat tertentu. Dalam literatur fikih juga tidak disyaratkan talak harus dilakukan di tempat tertentu. Talak dalam Islam bisa dilakukan di mana saja, baik secara lisan maupun tulisan. ${ }^{45}$ Demikian juga dalam hukum di Malaysia, telah tetap dipandang sah jika suami menjatuhkannya di luar mahkamah. Aturan tambahannya yaitu adanya kewajiban bagi suami melaporkan ke pihak mahkamah agar diproses secara hukum formal. Adapun ketentuan keharusan melaporkan talak tersebut dimuat dalam Seksyen 57 yang mengatur tentang pendaftaran perceraian di luar Mahkamah, dalam Enakmen Undang-Undang Keluarga Islam (Negeri Selangor) 2003.

(1) Walau apa pun seksyen 55, seseorang yang telah menceraikan isterinya dengan lafaz talaq di luar Mahkamah dan tanpa kebenaran Mahkamah, hendaklah dalam masa tujuh hari dari pelafazan talaq itu melaporkan kepada Mahkamah. (2) Mahkamah hendaklah mengadakan siasatan untuk memastikan sama ada talaq yang dilafazkan itu adalah sah mengikut Hukum Syarak.(3) Jika Mahkamah berpuashati bahawa talaq yang telah dilafazkan itu adalah sah mengikut Hukum Syarak, maka Mahkamah hendaklah, tertakluk kepada seksyen 125: (a)membuat perintah membenarkan perceraian dengan talaq(b)merekodkan perceraian itu dan(c)menghantar salinan rekod itu kepada Pendaftar yang berkenaan dan kepada Ketua Pendaftar bagi pendaftaran. ${ }^{46}$

Masih menurut Tuan Abdul Hadi, statistik perceraian luar mahkamah ini banyak dilakukan, tetapi yang mempunyai kesadaran untuk mendaftar kepada mahkamah itu yang kurang. ${ }^{47}$ Atas dasar banyaknya pelanggaran talak ini, Mahkamah Rendah Syariah Selangor merasa perlu untuk membebankan sanksi hukum kepada pelaku agar lafaz talak tidak diucapkan sembarangan tanpa mengikuti prosedur yang disebutkan dalam Enakmen Hukum Keluarga Islam Selangor. Mahkamah Rendah Syariah Negeri Selangor menetapkan sanksi

43 'Hasil Wawancara Dengan Tuan Abdul Hadi, Hakim II Pada Mahkamah Rendah Syariah Selangor, Tanggal 26 Januari 2018.'

44 Ibid.

45 Imam Abī Muhammad al-Husain bin Mas'ūd bin Muhammad bin al-Farrā' al-Baghawī (n 15), hlm. 6-10; Lihat juga dalam Amir Syarifuddin, Hukum Perkawinan Islam Di Indonesia: Antara Fiqh Munakahat Dan Undang-Undang Perkawinan (Kencana Prenada Media Group 2009), hlm. 226.

46 'Government of Selangor Gazette, Warta Kerajaan Negeri Selangor: Enakmen Undang-Undang Keluarga Islam (Neger Selangor) 2003, (Kerajaan Negeri Selangor: Tambahan No. 1 Enakmen, 2003)', hlm. 194-195.

'Hasil Wawancara Dengan Tuan Abdul Hadi, Hakim II Pada Mahkamah Rendah Syariah Selangor, Tanggal 26 Januari 2018.' (n 43). 
dalam undang-undang keluarga Islam adalah sebuah kebijakan pemerintah terhadap negara bagian masing-masing. Ia dapat memainkan peran yang sangat besar karena bagi siapa saja yang melakukan kesalahan akan dikenakan sanksi. Namun, perceraian tetap banyak terjadi walaupun di Malaysia sudah diatur sanksinya. Dengan adanya aturan sanksi tersebut, dapat mengelakkan suami menceraikan isteri dengan sewenang-wenang tanpa sebab yang sepatutnya dan terhindarnya talak di luar Mahkamah Syariah. Ini karena akibat dari perceraian di luar mahkamah syariah sukar untuk didiselesaikan seterusnya. Selain itu, isteri yang diceraikan dengan sah menurut hukum syara' tanpa memenuhi syarat menurut undang-undang, maka yang dirugikan adalah isteri.

Bagi pihak yang ingin bercerai mematuhi undang-undang serta sesuai menurut hukum Islam, maka dapat terpelihara dari perbuatan yang sewenang-wenang. Walaupun begitu, perceraian di luar mahkamah merupakan kasus yang paling tinggi. Terhadap pelaku talak di luar mahkamah akan dikenakan sanksi dari pemerintah. Penetapakan sanksi tersebut disebabkan oleh beberapa faktor dan alasan tersendiri. Terkait dengan faktorfaktor yang mempengaruhi pelaksanaan sanksi talak di luar Mahkamah Rendah Syari'ah Selangor, secara umum dipengaruhi oleh dua faktor, yaitu: Pertama, Enakmen telah diatur hukum perceraian di luar mahkamah secara rinci dan jelas, namun masyarakat masih kurang sosialisasi dan mengambil berat terhadap aturan ini sehingga penerapan sanksi atas kasus talak di luar mahkamah muncul sebagai solusi hukumnya. Kedua, banyaknya temuan kasus talak di luar mahkamah.

Dua faktor inilah sebagai alasan penerapan sanksi hukum talak di luar mahkamah. Berikut ini akan dijelaskan kedua faktor tersebut dilihat dari aspek kenyataan empiris serta aspek normatif hukum yang ada di Selangor.

Pertama: Tidak ada ketentuan tegas dalam Enakmen Hukum Keluarga Islam Selangor tentang kewajiban talak di mahakamah

Kaitannya dengan faktor pertama, terdapat keterangan bahwa aturan undang-undang hukum keluarga khususnya dalam hal talak di luar mahkamah tampak sudahh cukop tegas. Katiadaan kewajiban melakukan talak di mahkamah dan hanya berpegang pada ketentuan hukum Islam menimbulkan banyak pihak memandang talak hanya mengikuti aturan hukum Islam semata. Tuan Abdul Hadi mengumpamakan ketentuan talak di Indonesia. hukum keluarga di Indonesia menetapkan talak hanya dapat dilakukan di depan persidangan (di mahkamah). Jika talak dilakukan di luar pengadilan, maka pasangan suami isteri yang telah bercerai tidak mempunyai kewenangan untuk menuntut hak-hak pasca talak, seperti harta bersama, pengasuhan, dan nafkah iddah. Lebih lanjut, ditegaskan bahwa di Indoneisa, memang tidak disebutkan secara ekplisit sanksi hukum talak di luar pengadilan. Tetapi, sulitnya bagi masing-masing pasangan untuk mengurus hak selepas perceraian menjadi sanksi tersendiri atas peristiwa hukum yang tidak mengikuti ketentuan hukum di Indinesia. Aturan semacam inilah yang tidak disebutkan secara ekplisit dalam Enakmen Hukum Keluarga Islam Selangor, sehingga mengharuskan bagi mahkamah untuk melaksanakan sanksi hukum tersendiri terhadap talak di luar mahkamah. ${ }^{48}$

Keterangan lainnya juga dinyatakan oleh Arisha, salah seorang karyawan kerajaan. Ia menyatakan bahwaketentuan peraturan undang-undang hukum keluarga di Selangor cukup baik. Selama ini, kasus-kasus hukum keluarga bisa diselesaikan menurut aturan tersebut. Tetapi, dalam pengaturan perceraian talak, memang belum dirinci, misalnya aturan tentang keharusan melakukan talak di mahkamah. Meskipun terdapat keharusan bagi suami untuk melaporkan talaknya ke mahkamah dalam tempoh 7 (tujuh) hari setelah

48 Ibid. 
lafaz talak di ucapkan, akan tetapi aturan ini masih belum tegas. Sanksi hukumnya tidak disebutkan, sehingga kasus-kasus talak tetap dan besar kemungkinan akan tetap terjadi. Untuk itu, penerapan sanksi talak di luar mahkamah di Mahkamah Rendah Syariah Selangor dipandang perlu untuk diterapkan. ${ }^{49}$

Berdasarkan keterangan di atas, dapat dipahami bahwa ketentuan undang-undang yang belum merinci aturan talak menjadi faktor munculnya penerapan sanksi bagi pelaku talak di luar mahkamah. Hal ini membuktikan bahwa aturan tegas di dalam enakmen mempengaruhi kebijakan tentang penerapan sanksi talak di luar mahkamah pada Mahkamah Rendah Syariah Selangor namun masyarakat masih kurang tersosialisasi terhadap enakmen tersebut.

Kedua: Banyaknya temuan kasus talak di luar mahkamah.

Faktor kedua yang mempengaruhi penerapan sanksi talak di luar Mahkamah rendah Syariah Selangor adalah kasus-kasus cerai talak banyak ditemukan di lapangan. Temuan kasus talak di luar mahkamah ada yang dilaporkan ke pihak mahkamah, tidak sedikit juga talak yang tidak dilaporkan ke mahkamah. Hal ini menjadi polemik tersendiri, sehingga menjadi alasan ditetapkannya sanksi bagi pelaku talak di luar makahamah. Berdasarkan data yang diberikan oleh pihak mahkamah, sejumlah 7 (tujuh) kasus talak di luar Mahkamah Rendah Syariah Selangor yang berhasil diputuskan dan diberikan sanksi hukum. Ketujuh kasus tersebut terjadi dari tahun 2015, 2016, dan tahun 2017. Adapun klasifikasi kasus talak tersebut dapat dilihat dalam tabel berikut ini.

Tabel: Klasifikasi Talak di Luar Mahkamah Rendah Gombak Barat, Selangor

\begin{tabular}{|c|c|c|c|c|c|}
\hline No & Penggugat & $\begin{array}{l}\text { Ter- } \\
\text { gugat }\end{array}$ & $\begin{array}{c}\text { Alasan } \\
\text { Kasus }\end{array}$ & $\begin{array}{l}\text { Sanksi } \\
\text { Hukum }\end{array}$ & $\begin{array}{c}\text { Tanggal } \\
\text { Daftar } \\
\text { Kasus/ } \\
\text { Nomor }\end{array}$ \\
\hline 1 & $\begin{array}{c}\text { Nooraziah } \\
\text { Binti } \\
\text { Ya'acob }\end{array}$ & $\begin{array}{c}\text { Mohd } \\
\text { Izam Bin } \\
\text { Mispardi }\end{array}$ & $\begin{array}{c}\text { Talak dilafazkan secara } \\
\text { lisan pada jam } 10.30 \\
\text { pagi tanpa kebenaran } \\
\text { mahkamah terjadi } \\
\text { di rumah karena } \\
\text { isteri coba menuntut } \\
\text { melebihi batas } \\
\text { kemampuan suami } \\
\text { dengan lafaz "Aku } \\
\text { ceraikan Kau" }\end{array}$ & $\begin{array}{l}\text { Lafaz cerai disahkan } \\
\text { oleh mahkamah } \\
\text { dengan jatuh } \\
\text { talak } 1 \text { ( Talak } \\
\text { Rajie). Mahkamah } \\
\text { mensabitkan sanksi } \\
\text { kepada Mohd } \\
\text { Izam Bin Mispardi } \\
\text { sebanyak Rm1000 } \\
\text { (Rp 3,000.000) atau } \\
\text { 14 hari penjara }\end{array}$ & $\begin{array}{c}2 \text { Januari } \\
2015 / \text { No } \\
\text { 1008-167- } \\
0002-2015\end{array}$ \\
\hline 2 & $\begin{array}{l}\text { Che Puan } \\
\text { Binti } \\
\text { Abdullah }\end{array}$ & $\begin{array}{l}\text { Mohd } \\
\text { Roslan } \\
\text { Bin } \\
\text { Yahya }\end{array}$ & $\begin{array}{l}\text { Talak dilafazkan } \\
\text { secara lisan pada } \\
\text { jam } 10.56 \text { pagi di } \\
\text { rumah karena terjadi } \\
\text { sering percecokkan } \\
\text { beralamat di atas } \\
\text { dengan tanpa } \\
\text { kebenaran mahkamah }\end{array}$ & $\begin{array}{c}\text { Lafaz cerai disahkan } \\
\text { oleh Mahkamah } \\
\text { dengan jatuh talak } 1 \\
\text { kali pertama (Talaq } \\
\text { Rajie). Mahkamah } \\
\text { Mensabitkan sanksi } \\
\text { kepada Mohd Bin } \\
\text { Roslan sebanyak } \\
\text { Rm400 (Rp } \\
\text { 1,450.000) atau } 7 \\
\text { hari penjara }\end{array}$ & $\begin{array}{c}20 \text { Agustus } \\
2015 / \text { No. } \\
10008-167- \\
176-2015\end{array}$ \\
\hline
\end{tabular}

49 'Hasil Wawancara Dengan Arisha Binti Apkhar, Karyawan Kerajaan, Tanggal 28 Januari 2018.' 


\begin{tabular}{|c|c|c|c|c|c|}
\hline 3 & $\begin{array}{l}\text { Siti Nur } \\
\text { Aishah } \\
\text { Binti Abdul } \\
\text { Ghani }\end{array}$ & $\begin{array}{l}\text { Mohd } \\
\text { Faiez Bin } \\
\text { Adnan }\end{array}$ & $\begin{array}{c}\text { Talak dilafazkan } \\
\text { secara lisan pada } \\
\text { jama } 11.30 \text { malam } \\
\text { di rumah karena } \\
\text { terjadi percecokkan } \\
\text { besarantara pasangan }\end{array}$ & $\begin{array}{c}\text { Lafaz cerai telah } \\
\text { disahkan oleh } \\
\text { mahkamah } \\
\text { dengan talaq } 3 \\
\text { secara Talak Bain } \\
\text { Kubra). Mahkamah } \\
\text { mensabitkan sanksi } \\
\text { kepada Mohd Faiez } \\
\text { Bin Adnan sebanyak } \\
\text { Rm 1000 ( Rp } \\
\text { 3,000.000) atau } 21 \\
\text { hari penjara }\end{array}$ & $\begin{array}{l}15 \text { Januari } \\
\text { 2016/No. } \\
\text { 1008-167- } \\
0012-2016\end{array}$ \\
\hline 4 & $\begin{array}{l}\text { Salmi Binti } \\
\text { Moham- } \\
\text { mad }\end{array}$ & $\begin{array}{l}\text { Mohd } \\
\text { Zaid Bin } \\
\text { Hamidun }\end{array}$ & $\begin{array}{c}\text { Talak dilafazkan secara } \\
\text { sms( sistem pesanan } \\
\text { singkat) pada jam } \\
10.45 \text { pagi karena } \\
\text { permasalahan sering } \\
\text { dicampur tangan } \\
\text { mertua }\end{array}$ & $\begin{array}{c}\text { Lafaz cerai talak } \\
\text { disahkan oleh } \\
\text { mahkamah secara } \\
\text { talak } 1 \text { ( talak } \\
\text { Raji'i). Mahkamah } \\
\text { mensabitkan } \\
\text { kesalahan rm400 ( } \\
\text { rp 1,400.000) atau } 5 \\
\text { hari penjara }\end{array}$ & $\begin{array}{l}8 \text { September } \\
2016 / \text { No. } \\
10008-167- \\
0121-2016 .\end{array}$ \\
\hline 5 & $\begin{array}{l}\text { Norhazirah } \\
\text { Binti Mohd } \\
\text { Zahid }\end{array}$ & $\begin{array}{l}\text { Muham- } \\
\text { mad } \\
\text { Azrul } \\
\text { Naim Bin } \\
\text { Adnan }\end{array}$ & $\begin{array}{l}\text { Talak dilafazkan secara } \\
\text { lisan pada jam } 5.30 \\
\text { sore di parkir kantor } \\
\text { dengan talak } 1 \text { tanpa } \\
\text { kebenaran mahkamah. }\end{array}$ & $\begin{array}{c}\text { Lafaz cerai telah } \\
\text { disahkan oleh } \\
\text { mahkamah talak } \\
1 \text { ( talak Rajie. } \\
\text { Mahkamah } \\
\text { memutuskan Rm500 } \\
\text { ( Rp 1,770.000) atau } \\
\text { penjara } 10 \text { hari }\end{array}$ & $\begin{array}{l}20 \text { Juli2017/ } \\
\text { No. } 10008- \\
167-0145- \\
2017\end{array}$ \\
\hline \multirow[t]{2}{*}{6} & $\begin{array}{l}\text { Rohana } \\
\text { Azimah } \\
\text { Binti } \\
\text { Azman }\end{array}$ & $\begin{array}{l}\text { Muham- } \\
\text { mad } \\
\text { Ali Bin } \\
\text { Saifullah }\end{array}$ & $\begin{array}{c}\text { Talak dilafazkan } \\
\text { secara lisan pada } \\
\text { jam } 8.30 \text { malam di } \\
\text { rumah karena tergugat } \\
\text { mengabaikan }\end{array}$ & $\begin{array}{c}\text { Lafaz cerai talak } \\
\text { disahkan oleh } \\
\text { mahkamah dengan } \\
\text { talak } 1 \text { ( talak } \\
\text { Raji'i). Mahkamah } \\
\text { mensabitkan sanksi } \\
\text { sebanyak }\end{array}$ & $\begin{array}{l}14 \text { September } \\
2017 / \text { No. } \\
10008-167- \\
0184-2017 .\end{array}$ \\
\hline & & & $\begin{array}{c}\text { keluarga baik } \\
\text { tanggungjawab dan } \\
\text { nafkah pada isteri dan } \\
\text { anak. }\end{array}$ & $\begin{array}{c}\text { RM } 300(\mathrm{Rp} \\
\text { 1,000.000) atau } 4 \\
\text { hari penjara. }\end{array}$ & \\
\hline 7 & $\begin{array}{l}\text { Shezlin } \\
\text { Eleda Binti } \\
\text { Shaharud- } \\
\text { din }\end{array}$ & $\begin{array}{l}\text { Muham- } \\
\text { mad Bin } \\
\text { Ahmad } \\
\text { Kamal }\end{array}$ & $\begin{array}{c}\text { Talak dilafazkan secara } \\
\text { lisan di perkarangan } \\
\text { pejabat pada jam } 3.00 \\
\text { sore dengan talak } 1\end{array}$ & $\begin{array}{c}\text { Lafaz cerai telak } \\
\text { disahkan oleh } \\
\text { mahkamah secara } \\
\text { talak } 1 \text { ( talak } \\
\text { Rajie). Mahkamah } \\
\text { mensabitkan sanksi } \\
\text { kepada Muhammad } \\
\text { Bin Ahmad Kamal } \\
\text { sebanyak Rm700 (Rp } \\
\text { 2,400.000) atau } 7 \\
\text { hari penjara }\end{array}$ & $\begin{array}{l}19 \text { September } \\
2017 / \text { No } \\
10008-167- \\
0184-2017 .\end{array}$ \\
\hline
\end{tabular}


Temuan beberapa kasus seperti tersebut di tabel di atas tentu menjadi pertimbangan sendiri bagi Mahkamah Rendah Syariah Gombak Barat Selangor dalam menetapkan sanksi talak di luar mahkamah. Selain ketujuh kasus di atas, masih banyak lagi kasus dalam realita masyarakat terkait cerai talak di luar mahkamah. ${ }^{50} \mathrm{Hal}$ ini disebabkan oleh pandangan bahwa sahnya talak dalam Islam tidak mesti dilakukan di mahkamah, tetapi boleh di mana saja dengan tetap melihat syarat dan ketentuan talak. Menurut Aiza binti Abdul Patah, salah seorang pengajar menyebutkan bahwa terjadinya talak di luar mahkamah sebab masyarakat memandang talak itu sah ketika memenuhi syarat dan rukunnya karena talak di mahkamah bukanlah syarat syar'i dan antara yang lain juga masyarakat kurang mengambil berat tentang aturan yang telah diatur oleh Enakmen Undang-Undang keluarga Islam Selangor. ${ }^{51}$

Temuan-temuan kasus talak di luar mahkamah seperti tersebut di atas, baik yang didaftarkan atau tidak, mempengaruhi Mahkamah Rendah Syariah Selangur membuat aturan sanksi bagi seseorang (suami) yang mentalak isteri di luar mahkamah. Intinya, dua faktor tersebut, baik karena faktor kurang rincinya aturan hukum keluarga, maupun banyaknya temuan kasus talak di luar mahkamah, menjadi penyebab diterapkannya sanksi talak di luar mahkamah.

\section{Efektivitas Pelaksanaan Sanksi Talak di Luar Mahkamah Rendah Syariah Selangor} Cerai talak yang terjadi dalam realita masyarakat Selangor disebabkan oleh beberapa alasan. Tuan Abdul Hadi mengemukakan, di antara alasan sering terjadinya talak karena pihak pasangan suami isteri sering mengalami percekcokkan, tidak memenuhi hak dan kewajiban sebagai pasangan, ada unsur orang ketiga, faktor ekonomi, campur tangan dari keluarga mertua, pernikahan dini yang mana sudah tidak efektif kursus pra pernikahan selama dua hari bagi pasangan yang mana seeloknya dibuat lebih lama sehingga setiap pasangan benar-benar mengerti makna pernikahan. ${ }^{52}$ Intinya, penyebab perceraian tersebut secara umum berlaku untuk semua kasus yang terjadi di realita masyarakat.

Terkiat dengan pelaksanaan sanksi atas kasus talak di luar mahkamah di Selangor memiliki efek positif tersendiri dalam kehidupan masyarakat. Artinya, pelaksanaan sanksi sangat efektif diterapkan. Penerapan sanksi tersebut sangat berpengaruh terhadap jumlah perceraian, kehati-hatian suami dalam melaflkan talak semakin tinggi. Hal ini pernah disinggung oleh Tuan Abdul Hadi, bahwa penerapan sanksi dalam kasus tersebut sebenarnya telah lama dilakukan. Lebih lanjut, dinyatakan bahwa kasus talak di luar mahkamah cukup banyak, baik yang didaftarkan maupun tidak. Sejauh penerapan sanksi tersebut, kasus-kasus talak di luar mahkamah telah terjadi penurunan. Berkisar antara tahun 2015 sampai degan 2017, hanya ditemukan 7 (tujuh) kasus talak di luar mahkamah yang didaftarkan pada Mahkamah Rendah Syariah Gombak Barat, Selangor. ${ }^{53}$ Dilihat dari kasus talak yang dilaporkan pada Mahkamah Rendah Selangor, sebenarnya cukup banyak, hingga mencapai 2.436 kasus talak yang didaftarkan sebab talak di luar mahkamah. Julah tersebut terhitung sejak tahun 2010 hingga tahun 2017. Adapun klasifikasinya dapat dilihat dalam tabel berikut ini:

\section{Tabel: Statistik Pendaftaran Kes Jenayah Penalti Perceraian Tanpa Kebenaran Mahkamah Kod 167 Mahkamah Syariah Selangor 2012-2017.}

\footnotetext{
50 'Hasil Wawancara Dengan Tuan Abdul Hadi, Hakim II Pada Mahkamah Rendah Syariah Selangor, Tanggal 26 Januari 2018.' (n 43).

51 'Hasil Wawancara Dengan Aiza Binti Abdul Patah, Pengajar, Tanggal 28 Januari 2018'.

52 'Hasil Wawancara Dengan Tuan Abdul Hadi, Hakim II Pada Mahkamah Rendah Syariah Selangor, Tanggal 26 Januari 2018.' (n 43). Ibid.
} 


\begin{tabular}{|c|c|c|c|c|}
\hline BIL & TAHUN & $\begin{array}{c}\text { JUMLAH PENDAFTARAN } \\
\text { KES }\end{array}$ & $\begin{array}{c}\text { Peratusan\% } \\
\text { Kasus Efektif }\end{array}$ & $\begin{array}{c}\text { Peratusan\% } \\
\text { Kasus Tidak } \\
\text { Efektif }\end{array}$ \\
\hline 1 & 2012 & 167 & $6.8 \%$ & - \\
\hline 2 & 2013 & 242 & - & $9.9 \%$ \\
\hline 3 & 2014 & 342 & - & $14.0 \%$ \\
\hline 4 & 2015 & 568 & - & $23.3 \%$ \\
\hline 5 & 2016 & 601 & $21.1 \%$ & $24.6 \%$ \\
\hline 6 & 2017 & 516 & $\mathbf{2 7 . 9 \%}$ & $\mathbf{7 1 . 8 \%}$ \\
\hline & JUMLAH & $\mathbf{2 . 4 3 6}$ & & - \\
\hline
\end{tabular}

Besaran jumlah kasus di atas sebenernya berlaku umum ditangani pada Mahkamah Rendah Selangor, namun khusus untuk kasus talak pada Mahkamah Rendah Syariah Gombak Barat Selangor cukup sedikit seperti telah disebutkan sebelumnya, yaitu beberapa kasus dalam kurun waktu antara tahun 2015 hingga tahun 2017. Dalam hal ini, penurunan jumlah kasus talak di luar mahkamah pada Mahkamah Rendah Syariah Gombak Barat Selangor diduga kuat karena penerapan sanksi dari pihak mahkamah kepada laki-laki yang mentalak. Hal ini pernah disinggung sebelumnya oleh Tuan Abdul Hadi, selaku Hakim II Mahkamah Rendah Syariah Gombak Barat.

Selain mengurangnya kasus talak di luar mahkamah, pelaksanaan sanksi juga efektif berpengaruh bagi kemaslahatan masyarakat, tepatnya dalam membangun keluarga agar tetap utuh, dan suami tidak sewenang-wenang menggunakan hak talaknya. ${ }^{54}$ Sekarang ini, ada wacana dari Mahkamah Rendah Syariah Gombak Barat Selangor untuk meninggikan sanksi hukum bagi pelaku talak di luar mahkamah. Ketentuan yang berlaku selama ini yaitu bagi suami yang mentalak isteri di luar mahkamah, dibebankan untuk membayar tidak melebihi RM 1000 (Rp 3,000.000) atau tidak melebihi 6 bulan penjara. Ketentuan ini menurut Tuan Abdul Hadi cukup mudah dan ringan sekali meskipun ada pengaruh yang sangat signifikan. Usaha dan wacana untuk meningkatkan jumlah sanksi masih dalam proses pembicaraan pihak Mahkamah. Hal ini dilakukanagar penjatuhan sanksi benar-benar efektif dilakukan. ${ }^{55}$

Berangkat dari uraian di atas, dapat disimpulkan bahwa penerapan sanksi hukum bagi suami yang mentalak isteri di luar Mahkamah sangat efektif dalam mengurangi jumlah cerai talak du luar mahkamah, menciptakan kemaslahatan bagi masyarakat, khususnya dalam membina tali nikah agar tetap bersatu, serta untuk memberi pelajaran kepada masyarakat agar tidak menjatuhkan talak di luar mahkamah.

\section{Tinjauan Hukum Islam terhadap Sanksi Talak di Luar Mahkamah}

Talak dalam hukum Islam merupakan hak prerogatif suami yang dapat digukanan sewaktuwaktu ketika diperlukan. Hak prerogatif tersebut tentu tidak bisa digunakan secara serta merta, tanpa ada latar belakang yang mendahuluinya. Misalnya, karena watak dan karakter yang susah untuk dipersatukan dan menjadi pintu masuk pertengkaran pasangan suami isteri, masing-masing tidak menjalakan kewajiban sebagaimana telah ditetapkan dalam Alquran dan hadis, dan hal-hal lainnya. Intinya, talak bisa digunakan ketika suami telah benar-benar melihat tidak adanya celah untuk mempersatukan lagi tali pernikahan.

54 'Hasil Wawancara Dengan Arisha Binti Apkhar, Karyawan Kerajaan, Tanggal 28 Januari 2018.' (n 49); 'Hasil Wawancara Dengan Aiza Binti Abdul Patah, Pengajar, Tanggal 28 Januari 2018' (n 51).

55 'Hasil Wawancara Dengan Tuan Abdul Hadi, Hakim II Pada Mahkamah Rendah Syariah Selangor, Tanggal 26 Januari 2018.' (n 43). 
Terkait dengan hukum cerai talak dewasa ini, di negara-negara muslim dunia memang diatur sekumpulan peristiwa hukum keluarga, termasuk talak di dalamnya. ${ }^{56}$ Amiur Nuruddin ${ }^{57}$ dan Abdul Manan ${ }^{58}$ misalnya, menyebutkan sistem hukum dewasa ini tidak lagi mengacu pada sistem oral (perkataan), tetapi semua peristiwa hukum harus dicatatkan, termasuk pencatatan kebenaran telah terjadinya talak dalam sebuah pasangan. Sistem hukum dewasa ini mengharuskan suami yang ingin mentalak isteri agar mengajukan permohonan cerainya kepada pihak mahkamah. Dalam sudut ini, aturan talak harus di dalam mahkamah dan dicatatkan, dua ketentuan umum ini tidak menyalahi hukum Islam. Demikian juga aturan sanksi bagi pihak yang menjatuhkan talak di luar pengadilan.

Islam tidak mengatur adanya sanksi dalam talak, dalam hal ini suami bisa saja menyatakan cerai talak kepada isteri di mana saja, tidak terikat pada aturan hukum keharusan talak di tempat tertentu. Namun demikian, aturan hukum yang kemudian dibuat oleh pemeritah tidak menutup kemungkinan adanya mashlahat yang lebih besar. Dalam timbangan inilah, penerapan sanksi talak di luar mahkamah tidak bertentangan dengan hukum Islam. Dalam salah satu kaidah fikih disebutkan bahwa peraturan yang ditetapkan oleh pemerintah mengacu pada kemaslahatan masyarakat banyak. Adapun bunyinya adalah:

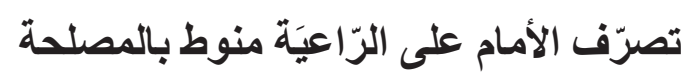

Tindakan imam terhadap rakyatnya harus dikaitkan dengan kemaslahatan.

Kaidah di atas memberikan gambaran hukum bahwa setiap tindakan, baik dalam bentuk peraturan atau kebijakan. Yang dimaksud imam dalam kaidah tersebut meliputi semua unsur pemerintahan, termasuk di dalamnya adalah pihak mahkamah. Contohnya, kebijakan Mahkamah Rendah Syariah Gombak Barat Selangor dalam menerapkan sanksi bagi pihak yang menjatuhkan cerai talak di luar mahkamah demi kemaslahatan masyarakat. ${ }^{59}$ Dasar hujjah kemaslahatan ini dapat dilihat dalam beberapa ayat Alquran, misalnya ketentuan surat al-Nisā' ayat 135.

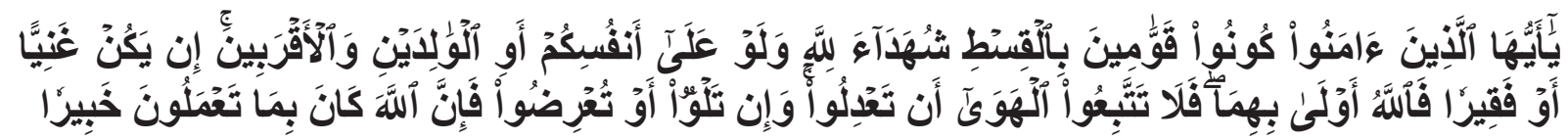

Wahai orang-orang yang beriman, jadilah kamu orang yang benar-benar penegak keadilan, menjadi saksi karena Allah biarpun terhadap dirimu sendiri atau ibu bapa dan kaum kerabatmu. jika ia kaya ataupun miskin, Maka Allah lebih tahu kemaslahatannya. Maka janganlah kamu mengikuti hawa nafsu karena ingin menyimpang dari kebenaran. dan jika kamu memutar balikkan (kata-kata) atau enggan menjadi saksi, Maka Sesungguhnya Allah adalah Maha mengetahui segala apa yang kamu kerjakan. (QS. Al-Nisä': 135).

Selain ayat di atas, juga di atur dalam surat al-Nūr ayat 49:

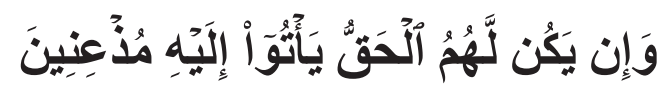

Tetapi jika keputusan itu untuk (kemaslahatan) mereka, mereka datang kepada Rasul dengan patuh. (QS. Al-Nūr: 49).

56 Muhammad Amin Suma, Hukum Keluarga Islam Di Dunia Islam (PT Raja Grafindo Persada 2005), hlm.227.

$57 \quad$ H. Amiur Nuruddin dan Azhari Akmal Trigan (n 2), hlm. 208.

58 Abdul Manan, Reformasi Hukum Islam Di Indonesia (PT Raja Grafindo Persada 2009), hlm. 109; Lihat juga dalam Abdul Manan, Aneka Masalah Hukum Perdata Di Indonesia (Kencana Prenada Media Group 2011), hlm. 252.

59 Bandingkan dengan Nurdin Bakri Nurdin Bakri and Antoni Antoni, 'Talak Di Luar Pengadilan Menurut Fatwa Mpu Aceh No 2 Tahun 2015 Tentang Talak’ (2017) 1 SAMARAH: Jurnal Hukum Keluarga dan Hukum Islam $52<$ http://jurnal.ar-raniry.ac.id/index.php/samarah/article/view/1570>. 
Dua ayat di atas setidaknya menjadi dasar bahwa pertimbangan kemaslahatan itu memang diperlukan dalam semua kebijakan, termasuk masuk dalam hal ini adalah kebijakan Mahakamah Rendah Syariah Gombak Barat dalam menerapkan sanksi terhadap talak di luar mahakamah. Berdasarkan hal tersebut, dapat disimpulkan bahwa penerapan sanksi dalam kasus cerai talak di luar mahkamah tidak bertentangan dengan hukum Islam. Meskipun ketentuan dalil syar'i tidak mengatur hal ini, bahkan dalam literatur fikih juga tidak ditemukan, tetapi atas pertimbangan kemaslahatan maka penerapan sanksi tidak menyalahi nilai-nilai hukum Islam.

\section{Penutup}

Mengamati dan menganalisa hasil pembahasan sebelumnya, maka dapat disimpulkan kepada tiga poin, yaitu: Pertama, faktor yang mempengaruhi pelaksanaan sanksi talak di luar Mahkamah Rendah Syariah Selangor ada dua. (1) Enakmen Hukum Keluarga Islam Negeri Selangor telah diatur hukum perceraian di luar mahkamah secara rinci dan jelas, namun masyarakat masih kurang sosialisasi dan mengambil berat terhadap aturan ini sehingga penerapan sanksi atas kasus talak di luar mahkamah muncul sebagai solusi hukumnya. (2) banyaknya temuan kasus talak di luar mahkamah mengharuskan adanya kebijakan hukum berupa penjatuhan sanksi hukum bagi pelakunya. Kedua: Pelaksanaan sanksi talak di luar Mahkamah Rendah Syariah Selangor masih kurang efektif dalam mengurangi perceraian. Kasus perceraian ditemukan cukup banyak di Selangor, namun kisaran kasus di Mahkamah Rendah Syariah Gombak Barat tahun 2015 hingga 2017 hanya ditemukan beberapa kasus yang terdaftar. Ketiga: Pelaksanaan sanksi talak di luar mahkamah tidak menyalahi hukum Islam. pelaksanaan sanksi hukum atas kasus talak di luar mahkamah dilandasai atas kemaslahatan masyarakat, mengatur tertib dan praktis talak secara berkeadilan sehingga suami tidak sewenang-wenang menjatuhkan talak.

\section{DAFTAR PUSTAKA}

'Abd al-Rāḥmān al-Jazīrī, Kitāb Al-Fiqh 'Alā Al-Mażāhib Al-Arba'Ah (Juz 5, Dār al-Kutb al'Ilimiyyah 2003)

\section{A. Hamid Sarong, Hukum Perkawinan Islam Di Indonesia (Yayasan PeNA 2010)}

Abd al-Wahhāb al-Khallāf, 'Ilm Al-Ușūl Al-Fiqh (Maktabah al-Da'wah al-Islamiyyah 1947)

Abdu Rahman Ghazaly, Fiqh Munakahat (Kencana Prenada Media Group 2006)

Abdul Aziz Muhammad Azzam dan Abdul Wahhab Sayyid Hawwas, Fiqh Munakahat (AlUsrah Wa Aḥkāmuhā Fī Li Al-Tasyrī’ Al-Islāmī) (Amzah 2011)

Abdul Manan, Reformasi Hukum Islam Di Indonesia (PT Raja Grafindo Persada 2009)

——, Aneka Masalah Hukum Perdata Di Indonesia (Kencana Prenada Media Group 2011)

Abī Dāwud Sulaimān bin al-Asy'aś al-Sajastānī, Sunan Abī Dāwud (Bait al-Afkār alDauliyyah Linnasyr)

Abī Ishạạ al-Syāțibī Ibrāhīm bin Mūsā al-Lakhmī al-Gharnāṭī al-Mālikī, Al-Muwāfaqāt Fī Ușūl Al-Syarī'ah (Dār al-Kutub al-'Ulumiyyah 2004)

Abī Muḥammad 'Izz al-Dīn 'Abd al-'Azīz bin 'Abd al-Salām al-Salamī, Qawā'id Al-Aḥkām Fī Mașāliḥ Al-Anām (Maktabah Kulliyyāt al-Azhariyyah 1994)

Abu Bakar Jabir al-Jazairi M al-M, Minhajul Muslim: Pedoman Hidup Seorang Muslim (Ummul Qura 2014)

Abu Malik Kamal bin al-Sayyid Salim, Fiqih Sunnah Wanita: Panduan Lengkap Wanita 
Muslimah (Fiqh Al-Sunnah Lin Nisā: Wa Mā Yajibu an Ta'rifuh Kulli Muslimah Min Ahkām) (Griya Ilmu Mandiri Sejahtera 2016)

Achmad Warson Munawwir dan Muhammad Fairuz, Al-Munawwir: Kamus Indonesia Arab (Pustaka Progressif 2007)

Al-Imām al-'Allāmah Muwaffiq al-Dīn Abī Muḥammad 'Abdullāh bin Aḥmad bin Maḥmūd bin Qudāmah, Al-Mughnī Al-Syarḥ Al-Kabīr (Juz 8, Dār al-Kutub al-'Arabī)

Al-Imām Muḥammad Abū Zahrah, Al-Aḥwāl Al-Syakhșiyyah (Dār al-Fikr al-'Arabī 1948)

Al-Zuḥailī W, Al-Fiqh Al-Islāmī Wa Adillatuh (Dār al-Fikr 1985)

Ali Yusuf al-Subki, Fiqh Keluarga (Niz̄ām Al-Usrah Fī Al-Islām) (Amzah 2010)

Amir Syarifuddin, Hukum Perkawinan Islam Di Indonesia: Antara Fiqh Munakahat Dan Undang-Undang Perkawinan (Kencana Prenada Media Group 2009)

Departmen Agama RI., Al-Qur'an Dan Terjemahan

'Enakmen 2 Tahun 2003, Enakmen Undang-Undang, Pentadbiran Keluarga Islam Pasal No 125, Tentang Perceraian Di Luar Mahkamah Dan Tanpa Kebenaran Mahkamah, Bahagian Kesalahan Dan Hukuman.'

Erny MA and Hidayati, 'Resiliensi Pada Anak Dari Keluarga Yang Broken Home'

'Government of Selangor Gazette, Warta Kerajaan Negeri Selangor: Enakmen UndangUndang Keluarga Islam (Neger Selangor) 2003, (Kerajaan Negeri Selangor: Tambahan No. 1 Enakmen, 2003)'

H. Aminur Nuruddin dan Azhari Akmal Tarigan, Hukum Perdata Islam Di Indonesia (Cet Ke-2, Pustaka Setia 2000)

H. Amiur Nuruddin dan Azhari Akmal Trigan, Hukum Perdata Islam Di Indonesia Studi Kritis Perkembangan Hukum Islam Dari Fikih, UU No 1/ 1974 Sampai KHI (Kencana Prenada Group 2004)

'Hasil Wawancara Dengan Aiza Binti Abdul Patah, Pengajar, Tanggal 28 Januari 2018'

'Hasil Wawancara Dengan Arisha Binti Apkhar, Karyawan Kerajaan, Tanggal 28 Januari 2018.'

'Hasil Wawancara Dengan Tuan Abdul Hadi, Hakim II Pada Mahkamah Rendah Syariah Selangor, Tanggal 26 Januari 2018.'

Heryanto, 'Pembinaan Keluarga Broken Home' [2016] Jurnal Edueksos

Ibnu Qayyim al-Jauziyyah, Tahżīb Al-Sunan Li Imām Ibn Qayyim (Maktabah al-Ma'ārif li al-Nasyr wa al-Tauz’’’ 2007)

Imam Abī Muhammad al-Ḥusain bin Mas'ūd bin Muhammad bin al-Farrā' al-Baghawī, AlTahżīb Fì Fiqh Al-Imàm Al-Syāfi'ì (Juz 6, Dār al-Kutub al-'Ulimiyyah 1997)

Imām al-Ḥāfiz Abī 'Abdillāh Muḥammad bin Ismā'īl al-Bukhārī, Șaḥịhal-Bukhārī (Bait alAfkār al-Dauliyyah Linnasyr 1998)

Jabatan Kehakiman Selangor, 'Statistik Perceraian Negeri Selangor' < Selangor. Kehakiman.gov.my> accessed 10 June 2017

Khoiruddin Nasution, Hukum Perkawinan 1 (Tazzafa \& ACAdeMIA 2004)

KW S, Rozano D and Utami T, 'Pengaruh Broken Home Terhadap Perilaku Agresif' [2016] Jurnal Penelitian Tindakan Bimbingan \& Konseling 
Mohd Naim Hj. Mokhtar, Talak: Konsep Dan Perlaksanaan Di Mahkamah Syariah (Dewan Pustaka 2003)

Muhammad Ali al-Sabuni, Hadiah Untuk Pengantin (Hadiyyah Al-'Afrah Li Al-'Arūsain AlZawāj Al-Islām Al-Mubakkir: Sa'Ādah Wa Hasānah) (Mustaqim 2004)

Muhammad Amin Suma, Hukum Keluarga Islam Di Dunia Islam (PT Raja Grafindo Persada 2005)

Nurdin Bakri NB and Antoni A, 'Talak Di Luar Pengadilan Menurut Fatwa Mpu Aceh No 2 Tahun 2015 Tentang Talak' (2017) 1 SAMARAH: Jurnal Hukum Keluarga dan Hukum Islam 52 <http://jurnal.ar-raniry.ac.id/index.php/samarah/article/ view/1570>

Rahmat Hakim, Hukum Perkawinan Islam (Cet Ke-2, Pustaka Setia 2000)

Santi MR, Koagouw F and Mingkid E, 'Pola Komunikasi Anak-Anak Delinkuen Pada Keluarga Broken Home Di Kelurahan Karombasan Selatan Kecamatan Wanea Kota Manado' [2015] 'Acta Diurna'

Satria Effendi M. Zein, Problematika Hukum Keluarga Islam Kontemporer: Analisis Yurisprudensi Dengan Pendekatan Ushuliyah (Kencana Prenada Group 2010)

Sayyid Sabiq, Fiqh Al-Sunnah (Pena Pundi Aksara 2006)

Syaikh al-Islām al-Imām al-'Allāmah Taqī al-Dīn Ibn Taimiyah, Syarh Kitāb Al-Siyāsah AlSyar'iyyah (Muḥamman bin Șāliḥ al-'Uśaimīn ed, Dār ibn Ḥazm 2004)

Syaikh Hasan Ayyub, Fikih Keluarga (Pustaka Al-Kausar 2006)

Syams al-Dīn Abī 'Abdillāh Muhammad bin Abī Bakr al-Zar'ī Ibn Qayyim al-Jauziyyah, Zād Al-Ma'ād Fī Hadī Khair Al-'Ibād (Juz 5, Mu'assasah al-Risālah 1998)

Syihāb al-Dīn Abī al-'Abbās Aḥmad bin Aḥmad bin Ḥamzah al-Ramlī, Fatḥ Al-Raḥmān Bi Syarḥ Zubad Ibn Ruslān (Dār al-Minhāj li al-Nasyr wa al-Taizì' 2009)

Ṭāhir A-Ḥabīb, Al-Fiqh Al-Mālikī Wa Adillatuh (Mu'assasah al-Ma'ārif 2005)

Wahbah al-Zuhaili, Fiqh Islam: Pernikahan, Talak, Khulu', Meng-Ila' Isteri, Li'an, Zihar, Masa Iddah (Jilid 9, Gema Insani Press 2011)

Yahya Abdurrahman al-Khatib, Fikih Wanita Hamil (Ậkām Al-Mar'ah Al-Hāmil Fī AlSyarī’ah Al-Islāmiyyah) (Qisthi Press 2011) 